Published in final edited form as:

Immunol Rev. 2017 November ; 280(1): 41-56. doi:10.1111/imr.12577.

\title{
ALARMINS AND IMMUNITY
}

\author{
De Yang ${ }^{\star}$, Zhen Han, and Joost J. Oppenheim * \\ Cancer and Inflammation Program, Center for Cancer Research, National Cancer Institute at \\ Frederick, National Institutes of Health
}

\section{SUMMARY}

More than a decade has passed since the conceptualization of the 'alarmin' hypothesis. The alarmin family has been expanding in terms of both number and the concept. It has recently become clear that alarmins play important roles as initiators and participarnts in a diverse range of physiological and pathophysiological processes such as host defense, regulation of gene expression, cellular homeostasis, wound healing, inflammation, allergy, autoimmunity, and oncogenesis. Here we provide a general view on the participation of alarmins in the induction of innate and adaptive immune responses, as well as their contribution to tumor immunity.

\section{Keywords}

Dendritic cells; Alarmin; Damage-associated molecular pattern; Immune response; and Tumor immunity

\section{INTRODUCTION}

Alarmins are endogenous, constitutively expressed, chemotactic and immune activating proteins/peptides that are released as a result of degranulation, cell injury or death or in response to immune induction. Alarmins function as intercellular signals defense by interacting with chemotactic and pattern recognition receptors (PRRs) to galvanize immune cells in host defense (1). Only when alarmins are released in excess by severe injuries and maximal stimulation do they result in the dangerous effects of potentially lethal cytokine storm. They have therefore also been considered damage-associated molecular patterns (DAMPs) (2) and this term has been used interchangeably with alarmins. In 2001, Polly Matzinger proposed that the immune system is geared to respond to DAMPs that resulted from microbial attack with ensuing cell injury and death (3). DAMPs were very broadly defined to include both exogenous pathogen associated molecular patterns (PAMPs) such as bacterial lipopolysaccharide (LPS), CpG oligodeoxynucleotide, and flagellin and deleterious endogenous products of damaged and dead cells (3). However, we prefer to identify the endogenous alarmins as a subset of endogenous DAMPs that interact with PRRs such as

\footnotetext{
“Correspondence: Drs. De Yang (Phone: 301-846-6450; Fax: 301-846-7042; yangd@ mail.nih.gov) and Joost J. Oppenheim (Phone: 301-846-1552; Fax: 301-846-7042; oppenheij@ mail.nih.gov), Rm31-19/21-89, Bldg 560, 1050 Boyles Street, Frederick, MD 21702-1201, USA.

DR. JOOST J. OPPENHEIM (Orcid ID : 0000-0003-0271-7921)

CONFLICT OF INTEREST

The authors have no conflict of interest.
} 
Toll-like receptors (TLRs) as cytokine-like mediators that participate in host defense and are usually not dangerous.

How did we arrive at this alarmin concept? A serendipitous observation initiated this research. In 1995 we performed a rather simplistic experiment to ensure that interleukin-8 (IL-8), an in vitro neutrophil chemoattractant, was also capable of attracting neutrophils in vivo. As expected, we observed that upon subcutaneous injection of IL-8 mice developed an acute inflammatory response characterized by neutrophilic infiltrates at $24 \mathrm{~h}$. However, we unexpectedly observed that the inflammatory site persisted and at $72 \mathrm{~h}$, was infiltrated only by mononuclear cells. We therefore hypothesized that neutrophils produced a chemoattractant for the monocytes/macrophages and predicted it to be a chemokine such as monocyte chemotactic peptide 1 (MCP-1/CCL2). Fortuitously our lab was joined at that time for a summer sabbatical by Dr. Oleg Chertov, a Russian biochemist. We asked him to determine the identity of the neutrophil derived attractant of mononuclear cells. He informed us several months later that it was a 1500 Dalton moiety. I informed him this was too small to be a chemokine and therefore undoubtedly a contaminant. He countered that he had performed the experiment three times and that the amino acid sequence of this small peptide identified it as a defensin (4). I asked him "what is a defensin?" Defensins had initially been identified in 1985 as "antimicrobial peptides" (AMPs) by Robert Lehrer and colleagues (5). Our data thus indicated they also interacted with inflammatory cells of the host and we reported our findings that these defensins mobilized cells engaged in host defense in several papers $(4,6,7)$ that were largely ignored until Dr. De Yang joined our laboratory and found out that human $\beta$ defensins interacted with the chemokine receptor CCR6 to induce the migration of immature dendritic cells (DCs) (8). This observation upset the chemokine research community because it "contaminated" their complicated network of chemokinereceptor interactions even more. It also upset the microbiologists who were studying the natural antibiotic activities of AMPs and were afraid to be outnumbered by immunologists preempting their studies on AMPs. Suffice it to state that neither discipline has suffered any interference or decline in their activities based on these observations.

The discovery of defensins' chemotactic activity was followed by the identification of the DC-activating property of $\beta$ defensins $(9,10)$. Subsequently, other granule-derived AMPs as well as the now famous high-mobility group box-1 (HMGB1) were shown to have both chemoattracting and activating effects on leukocytes including DCs and hence the capacity to induce innate and adaptive immune responses (11-26). This led us in 2004 to propose considering these endogenous moieties that can chemotactically mobilize and are also able to activate the immune system as endogenous alarmins $(1,27)$. Since alarmins are all constitutively expressed and rapidly released in response to infection and non-programmed cell death, they are available as "first responders" and by recruiting and activating leukocytes including dendritic cells (DCs), alarmins can initiate both innate/inflammatory and adaptive immune responses (28-34). Since then a plethora of additional host-derived molecules have been called alarmins. The definition of alarmins has been broadened to include endogenous moieties generated as a result of non-programmed cell death with the capacity to induce innate/inflammatory and adaptive immune responses (31, 32, 35-38). Currently, alarmins include a surprising number of chromatin-binding moieties in addition to HMGB1, such as 
HMGN1, IL-1a, and IL-33, as well as heat shock proteins (HSPs), S100 proteins, ATP, and uric acid crystals, which can be classified based on their origin (Table 1).

There are probably a number of alarmins that remain to be identified and little is as yet known about the clinical role of already identified alarmins. One intriguing example of this is our recent identification of a-synuclein as an alarmin (39). This protein is located in vesicles at nerve ends and released in response to microbial invaders, especially in the region of the gastrointestinal tract. Mutated variants of a-synuclein have been associated with early onset of familial Parkinson's disease. The relationship of the alarmin activity of a-synuclein and how it may cause chronic long term inflammatory CNS damage needs to be clarified.

Alarmins have been shown to participate in diverse processes including antimicrobial defense, regulation of gene expression, cellular homeostasis, wound healing, inflammation, allergy, immunity, autoimmunity, and oncogenesis. Below, we will focus on the roles of alarmins in the induction of innate and adaptive immune responses in general, as well as their contribution to tumor immunity.

\section{CONTRIBUTION OF ALARMINS TO INNATE IMMUNE RESPONSES}

The immune system relies on close collaboration of the innate and adaptive limbs to fend off any dangers (i.e. infection and/or cell damage) to the host. In response to microbial infection or sterile cell/tissue injury, alarmins/DAMPs are released and initiate innate/inflammatory immune responses $(1,28,29,31)$. Innate immune responses involve the activation of resident leukocytes [e.g. macrophages, DCs, mast cells (MCs), etc.], production of inflammatory mediators (cytokines, chemokines, and lipid metabolites), recruitment of neutrophils and monocytes/macrophages, and aims to eliminate invading microorganisms and injured tissues $(28,29)$.

\section{Alarmins activate leukocytes}

Mammalian a defensins induce degranulation and histamine release by MCs $(40,41)$. Human $\beta$ defensins, synthesized $\theta$ defensin, and cathelicidin/LL-37 also activate MCs leading to degranulation and release of histamine and prostaglandin $\mathrm{D}_{2}(14,42-44)$. Human a defensin and cathelicidin/LL-37 activate monocytes/macrophages, resulting in the production of IL-1, TNFa, IL-8, and CCL2 $(15,16)$. IL-1a and IL-33 activate MCs and basophils to induce MC maturation and release of inflammatory mediators including TNFa, IL-1 $\beta$, and IL-4 $(30,45,46)$. ATP promotes MC degranulation and production of inflammatory cytokines, chemokines and leukotrienes $(47,48)$. Uric acid crystals activate MCs for the production of nitride oxide, IL-1 $\beta$, and IL-6 $(49,50)$. Overall, many alarmins have the capacity to trigger MCs (and basophils) to produce/release histamine, prostaglandins, leukotrienes, proinflammatory chemokines and cytokines.

Defensins, cathelicidin, HMGB1 and HSPs have been shown to induce phagocytes (neutrophils and monocytes/macrophages) to produce a variety of inflammatory mediators including TNFa, IL-1 $\beta$, IL-6, IL-8, CCL2, CCL3 and CCL4, leukotriene B4, and nitride oxide $(13,17,26,33,51-62)$. Granulysin, ATP, and several S100 proteins also activate phagocytes to produce inflammatory mediators such as chemokines and cytokines (63-67). 
IL-1 $a$ and IL-33 promote the activation of phagocytes, resulting in distinct types of inflammatory responses $(30,34,68-70)$. Inflammatory mediators produced by phagocytes in response to various alarmins act collaboratively and orchestrate innate immune responses.

All alarmins identified so far have the capacity to activate DCs. Defensins activate conventional as well as plasmacytoid DCs either generated from DC progenitors/precursors in vitro or isolated from blood or skin $(9,10,71-75)$. Cathelicidin/LL-37 promotes DC activation alone or in complex with self or microbial nucleic acids $(18,61,76-78)$. EDN induces the maturation of human and mouse DCs $(24,79)$. Alarmins of nuclear origin (e.g. HMGB1, HMGN1, IL-1a, etc.) activate human and mouse conventional $(25,30,80-82)$ and plasmacytoid $(83,84)$ DCs. HSPs and certain S100 proteins such as S100A8/A9 (also known as calprotectin or Mrp8/14) have been shown to induce the maturation of bone marrow-derived and monocyte-derived DCs $(67,85-90)$. ATP and uric acid crystal stimulate DC maturation in vitro and in vivo (91-94). DC maturation/activation induced by all alarmins is characterized by upregulation of DC surface costimulatory (CD80 and CD86) and MHC (class I and II) molecules, induction of production of proinflammatory chemokines and cytokines such as TNFa, IL-1 $\beta$, IL-6, IL-8, CCL5, IL-10, and IL-12, and enhancement of the capacity to present antigens to lymphocytes resulting in the induction of adaptive immune responses. Nevertheless, DC-derived cytokines and chemokines also contribute to a pool of inflammatory mediators responsible for orchestrating innate immune responses.

\section{Alarmins participate in the activation of inflammasomes}

While most alarmins promote the expression and production of inflammatory cytokines by tissue resident leukocytes, IL-1 $\beta$ and IL-18, two of the IL- 1 superfamily cytokines, are produced in pro-forms and require cleavage by inflammasome-dependent activation of caspase 1 to become bioactive. Activation of caspase 1 requires the activation of several inflammasomes in macrophages. Inflammasomes are cytosolic molecular complexes assembled by NACHT, LRR and PYD domains-containing proteins (NLRP), apoptosisassociated specklike protein (ASC), and caspase 1 (95). Activation of inflammasomes is critical for innate/inflammatory responses and host defense. Interestingly, several alarmins have been reported to contribute to the activation of inflammasomes, in particular NLRP3. Uric acid crystal activates NLRP3 and caspase 1, resulting in the production of active IL-1 $\beta$ and IL-18 (96). HMGB1 elevates NLRP3 expression to a critical level for inflammasome formation (97). ATP is a well-known activator of NLRP3 inflammasome (94, 95, 98). Recently, an a defensin human neutrophil-derived peptide 1 (HNP1) has also been reported to promote NLRP3 inflammasome activation (52). Activation of NLRP3 inflammasome causes not only the maturation of IL-1 $\beta$ and IL-18, but also promotes the release of HMGB1 $(95,99)$, presumably forming a feedforward loop that amplifies innate immune responses.

\section{Alarmins induce the recruitment of leukocytes}

Alarmins chemoattract leukocytes-Recruitment of various leukocytes into danger sites is an essential step in innate/inflammatory response $(28,29)$. Many alarmins are chemotactic factors for diverse types of leukocytes. All vertebrate $\alpha$ - and $\beta$-defesnins tested are chemotactic for immature DCs, neutrophils, monocytes/macrophages, and certain 
subsets of T cells $(4,8,26,32,100-102)$. Human and mouse cathelicidins induce the migration of mast cells, neutrophils, and monocytes (12, 26, 44, 103, 104). EDN, HSPs, granulysin, S100 proteins, and HMGN1 are chemotactic for immature neutrophils, mast cells, monocytes, DCs, and NK cells (20, 32, 63, 82, 105-109). HMGB1 can induce the migration of neutrophils, monocytes/macrophages and DCs $(26,110,111)$. IL-33 is chemotactic for neutrophils and Th2 lymphocytes (112-114). Uric acid can chemoattract eosinophils (115) while ATP is chemotactic for many leukocytes (116). Given the importance of chemotactic factors in the induction of leukocyte extravasation and infiltration $(117,118)$, alarmins are definitively contributing directly to the infiltration of various leukocytes into sites of infection or tissue injury. Indeed, it has been shown that many alarmins induce the recruitment of granulocytes, macrophages, and DCs in vivo $(32,79,82$, 102, 119-122).

Alarmins indirectly promote the recruitment of leukocytes-Activation of various leukocytes by alarmins results in the production of many chemokines such as CXCL5, CXCL7, CXCL8, CXCL9, CXCL10, CXCL12, CCL2, CCL3, CCL5, CCL7, CCL8, and CCL20, which are well-established contributors to the recruitment of leukocytes during the development of innate immune responses $(117,118,123)$. Additionally, some alarmins also upregulate the expression of adhesion molecules by endothelial cells and leukocytes, for example, HMGB1 increases endothelial expression of ICAM-1, $\beta 1$ and $\beta 2$ integrins (124). Human $\beta$ 11efensing 2 has been shown to induce the arrest of Th17 cells on inflamed endothelial cells in an ICAM-1-dependent manner (125). Additionally, S100A8/A9 reduces neutrophil rolling and increase leukocyte adhesion by activating $\beta 2$ integrin (126). Because upregulation of adhesion molecules on endothelial cells and leukocytes is a prerequisite for leukocyte extravasation and movement into sites of inflammation $(118,123,127)$, alarmins by upregulating the expression of adhesion molecules on endothelial cells also promote the recruitment and infiltration of leukocytes during innate immune responses.

The ultimate goal of innate/inflammatory immune response is to eliminate dangers, such as invading microbes and/or damaged tissues. This is achieved through a wide range of mediators that form complex networks involving host release of alarmins in response to dangers, followed by activation of epithelial cells and leukocytes (MCs, macrophages, DCs, etc) in local tissues to produce a plethora of inflammatory mediators such as vasoactive amines and peptides, lipid metabolites (e.g. leukotrienes and prostaglandins), chemokines, and cytokines, which in turn orchestrate the recruitment of leukocytes (e.g. neutrophils, monocytes, and DCs) and activation of effectors (e.g. complement, phagocytes, etc) for the removal or sequestration of the invading pathogens or injured tissues to allow the host to restore functionality and homeostasis of the tissues. In this context, alarmins are critical as the warning signals reporting to the host the appearance of dangers by inducing the recruitment and activation of various leukocytes that are crucial for the innate/inflammatory responses. Many alarmins, such as defensins, cathelicidins, EDN, granulysin, and HMGB1 possess direct antimicrobial activities $(26,27,128,129)$ and therefore also contribute to eliminating pathogens and shaping the host's microbiota that, in turn, regulates immune responses and influence infection and inflammatory disorders. One example is cathelicidin. In patients with atopic dermatitis, a common Th-2 type inflammatory skin disorder, the lack 
of cathelicidin/LL-37 production due to suppression by high levels of IL-4 and IL-13 results in greatly reduced defense against vaccinia virus infection (130). Furthermore, it has recently been found that mouse cathelicidin/CRAMP is produced by pancreatic $\beta$-cells in response to certain short-chain fatty acids generated by gut microbiota, which modulates the pancreatic inflammation associated with diabetes. Non-obese diabetic (NOD) mice, due to deficiency in those short chain fatty acids, are defective in CRAMP production (131) and CRAMP administration to NOD mice dampens the development of autoimmune diabetes in NOD mice (131). Thus, alarmins in addition to networking with other endogenous host defense molecules also interact with exogenous agents influencing our host defense.

\section{ALARMIN-SENSING RECEPTORS AND SIGNAL TRANSDUCTION PATHWAYS}

Many receptors are employed by alarmins to alert host's immune system (Table 1). It has become clear that many alarmins use more than one receptors and some receptors are used by more than one alarmin. For examples, HMGB1 has been reported to use TLR2 (132), TLR4 (132, 133), RAGE $(56,84,133)$, and CXCR4 (121). TLR4 is used by many alarmins (Table 1). Of particular note, certain alarmins interact with exogenous pathogen-associated patterns (PAMPs) or endogenous mediators to form complexes that enable the activation of additional receptors. In this regard, cathelicidin forms complexes with microbial or host nucleic acids (RNA or DNA) that can trigger TLR7/8 $(78)$ or $\operatorname{TLR} 9(77,134)$, which are implicated in the inflammatory responses of autoimmune disorders (lupus and psoriasis) and atherosclerosis. $\beta$ defensins have also been shown to form complexes with DNA, which interacts with TLR9 to trigger the activation of plasmacytoid DCs (72). HMGB1 can also bind to complexes of DNA and anti-DNA autoantibody to activate plasmacytoid DCs via TLR9, which is thought to initiate/promote the autoimmune systemic lupus erythematosus (84). HMGB1, 2, and 3 bind with various nucleic acids in the cytosol and stimulate type I IFNs and inflammatory cytokines through triggering of TLR3, TLR7, and TLR9, which has been proposed as means for alarmins to sense viral infection (135). Thus, by binding to a variety of endogenous or exogenous molecules, alarmins can interact with additional receptors.

\section{Signal transduction pathways for alarmin-induced leukocyte activation}

Alarmins trigger PRRs, such as TLRs, receptor for glycation end-products (RAGE), P2X7, and NLRP3, and members of the IL-1R family including IL-1R1 and ST2 for the activation various leukocytes (Fig. 1). IL-1a and IL-33 act on IL-1R1 and ST2, respectively 4 (30, 45, 46). Defensins stimulate TLR4 on conventional DCs or TLR7/8/9 in plasmacytoid DCs for the induction of TNFa, IL-6, and IFN production via the activation of transcriptional factors NF- $\mathrm{kB}$, IRF3 and IRF7 $(10,72,75)$. Cathelicidin activates neutrophils, macrophages, DCs, and fibroblasts using TLR7,8, $9(77,78,134)$ or P2X7 $(55,136,137)$ for the induction of inflammatory mediators like TNFa, IFNa, COX2, and PGE2. EDN activates conventional DCs through triggering TLR2 and consequently the activation of NF- $\kappa B$ and multiple MAPKs, leading to the production of inflammatory cytokines such as TNFa, IL-6, IL-8 (24, 79). Many alarmins act on TLR4 to induce the production of various inflammatory mediators by macrophages or DCs, including $\beta$ defensins (10), HSPs $(62,88,89,138)$, 
HMGN1 (82), granulysin (119), S100 A8/A9 (66, 126, 139), and HMGB1 (132, 133).

Signal transduction through IL-1R1, ST2, and TLR2, TLR3, TLR4, TLR7, TLR8, TLR9, and RAGE relies on distinct adaptor proteins including MyD88, TRIF, TIRAP, and TRAM $(30,140,141)$. Despite the complexity of receptor usage and distinct receptor-proximal signaling effect, alarmins triggering TLRs, IL-1R1/ST2 and RAGE converge in the activation of transcriptional factors such as NF- $\mathrm{kB}$, IRFs, and AP-1, etc., which are responsible for promoting the transcriptional expression of mediators including many chemokines and cytokines (Fig. 1).

While most chemokines and cytokines are bioactive after translation and secretion, IL-1 $\beta$ and IL-18 are produced in macrophages and DCs as pro-forms that require cleavage by caspase 1 whose activation depends predominantly on the activation of NLRP3 inflammasome (30). The induction of the pro-forms of IL- $1 \beta$ and IL-18 can be promoted by many mediators including alarmins/DAMPs, PAMPs, and cytokines $(29,30,33,67,70,95$, 142). The activation of NLRP3 inflammasome requires two steps: upregulation of production and assembly $(30,95,143)$. The first step is mediated primarily by TLR adaptor MyD88- or cytokine-driven activation of NF- $\mathrm{kB}$, which promotes the production of NLRP3 $(95,143,144)$. Many alarmins can potentially contribute to this step, some of which has recently been confirmed (97). The second step involves the assembly of NLRP3, ASC, and pro-caspase 1 into a complex and autocatalytic cleavage of pro-caspase 1 into active caspase 1 , which in turn catalyzes IL-1 $\beta$; and IL-18 processing $(30,95,143)$. Several alarmins are shown to promote this step. ATP via P2X7 causes $\mathrm{K}^{+}$efflux to promote NLRP3 inflammasome assembly and activation $(95,98,145)$ and so do a 15 efensing and cathelicidin $(52,55,136,137)$. Uric acid crystals or even soluble uric acid upon entering into macrophages causes lysosomal rupture to release proteases such as cathepsin $\mathrm{B}$, which promote the activation of NLRP3 inflammasome and hence the production of active IL-1 $\beta$ and IL-18 $(95,96,146,147)$. Thus, it has been determined that alarmins can provide the necessary signals for the activation of NLRP3 inflammasome (Fig. 1).

\section{Signal transduction pathways for alarmin-induced leukocyte migration}

Leukocyte migration induced by most alarmins can be inhibited by pretreatment of the target cells with pertussis toxin, a bacterial toxin capable of preventing G proteins from interacting with GiPCRs on the cell membrane by catalyzing the ADP-ribosylation of the $a_{i}$ subunits of the heterotrimeric $\mathrm{G}$ protein $(8,11,12,20,63,81,100,103,104,148)$. This indicates that the direct chemotactic effects of many alarmins are mediated by GiPCRs (Fig. 1). $\beta$ defensins use CCR6 $(8,9,122,149,150)$ and CCR2 $(151,152)$ to induce the migration of DCs and monocytes/macrophages. Human and mouse cathelicidins induce the migration of leukocytes via FPRL1 or its mouse ortholog FPR2 $(12,104)$, however, human cathelicidin/ LL-37 induces mast cell migration and degranulation through MrgX2, a GiPCR belonging to Mas-related gene family (44). Recently, LL-37 has also been reported to induce neutrophil migration via CXCR2 (153). ATP uses several GiPCRs for inducing the migration of various target cells, such as P2Y2, P2Y6, and P2Y12 (116).

Receptors other than GiPCRs also participate in alarmin-induced leukocyte migration. HMGB1-induced migration of neutrophils, monocytes, and DCs is dependent on the 
presence of RAGE $(45,81,110,111,154)$. While S100A8- and S100A15-induced migration of neutrophils and macrophages is mediated by GiPCRs $(108,109)$, monocyte migration induced by S100A7 is RAGE-dependent (108). IL-33-induced cell migration is mediated by ST2 $(112,114)$.

Since many receptors mediating the chemotactic effects of alarmins are GiPCRs (e.g. FPRL1, CCR2, CCR6, etc.) whose signaling pathways have been elucidated in some details $(32,117,155,156)$, it is likely that alarmins trigger similar intracellular signaling pathways to those of chemoattractants and chemokines (Fig. 1). Briefly, binding of an alarmin with its GiPCR presumably result in the activation of heterotrimeric G-protein(s) that dissociate into activated $\mathrm{GaI}$ and $\mathrm{G} \beta \gamma$ subunits. Activated $\mathrm{GaI}$ and $\mathrm{G} \beta \mathrm{G} \gamma$ trigger the activation of two phospholipase C (PLC). PLC $\beta$, through inducing the generation of diacylglycerol (DAG) and elevation of cytoplasmic $\mathrm{Ca}^{2+}$, induces the activation of PKC. PLC $\gamma$ on the other hand activate PI3K and small GTPases (Rac and Rho), which, in turn, initiates a series of reactions that lead to the activation of Akt, ERKs, and LIM domain kinase (LIMK). Finally, PKC, Akt, Erks, and LIMK act in concert to rearrange cytoskeleton fibers leading to cell migration. Consistent with this scenario, cathelicidins have been shown to elevate intracellular $\mathrm{Ca}^{2+}$ in neutrophils, monocytes, and mast cells $(12,103,104,157)$. In addition, HMGB1-induced migration of glioblastoma cells depends on the activation of ERKs (158). Defensin-induced cell migration is accompanied by the activation of PI3K-Akt signaling pathway (159).

\section{CONTRIBUTION OF ALARMINS TO ADAPTIVE IMMUNE RESPONSES}

In addition to aiming for the elimination of dangers (microbes or dead/damaged cells), the innate/inflammatory immune responses also initiate adaptive immune responses by promoting antigen uptake, processing, and presentation. This is achieved by the induction of DC maturation/activation, an essential process for the induction of adaptive immune response because DCs matured/activated in the peripheral tissues upregulate CCR7 expression that enables DCs to home to draining lymph nodes by interacting with CCL19/21 expressed on high endothelial venules $(140,160,161)$. As discussed previously, all alarmins can promote the maturation/activation of DCs and hence contribute this essential step. Upon arrival in lymph nodes, matured/activated DCs induce antigen-specific activation, expansion, and differentiation of naïve $\mathrm{CD} 4^{+}$and $\mathrm{CD} 8^{+} \mathrm{T}$ cells into helper $\mathrm{CD} 4^{+} \mathrm{T}(\mathrm{Th})$ and $\mathrm{CD} 8^{+}$ cytotoxic lymphocyte (CTL) effector cells (162-164). Matured/activated DCs also pass intact antigens to follicular DCs for the activation of antigen-specific B cells in the germinal center, which is facilitated by activated Th cells $(140,161,165,166)$. Effectors (antibodies, helper $\mathrm{T}$ cells, cytotoxic $\mathrm{T}$ cells, etc) generated as a result of adaptive immune responses work in collaboration with the effectors of the innate immune system including granulocytes, macrophages, natural killer cells, and complement system to further promote the elimination of invading pathogens, damaged tissues, or oncogenic cells and to subsequently initiate tissue repair.

A second line of evidence supporting the capacity of alarmins to promote adaptive immunity has been obtained by administering alarmins together with antigens to induce antigenspecific immune responses. Intranasal co-administration of ovalbumin (OVA), an often used 
model antigen, and $a$-defensins enhances both humoral and cell-mediated OVA-specific immune responses in mice $(6,26)$. For $\beta$-defensins, engineered expression of mouse $\beta$ defensin 2 in a mouse leukemia cell line confers immunogenicity on the cell line, leading to the generation of protective immunity against the same tumor without the expression of mouse $\beta$-defensin 2 upon implantation into syngeneic immunocompetent mice (167). The generation protective immunity appears to be induced by activating DCs and relies on the presence of both NK and CD8 T cells, establishing induction of tumor-specific adaptive immune responses by $\beta$-defensin 2 (167). The capacity of $\beta$-defensins to induce adaptive immune responses have also been corroborated by the fact that DNA vaccination of certain $\beta$-defensins fused to a tumor or HIV antigen promoted the generation of antigen-specific systemic and mucosal immune responses $(9,10,168)$. Co-administration of OVA and cathelicidin/mouse CRAMP induces the recruitment of monocytes and neutrophils via one of the cathelicidin receptor FPR2 and promotes OVA-specific humoral and cell-mediated immune responses (104). Additionally, co-administration of OVA and HMGB1 (80), EDN (79), and HMGN1(82) have all been shown to promote generation of OVA-specific antibodies and cytokines derived from activated T cells, such as TNFa, IL-4, IL-5, IL-10, IL-13, and IFN $\gamma$. Furthermore, it has also been shown that S100A8/A9 participates in the development of autoreactive CD8 ${ }^{+}$effectors by signaling through TLR4 (139).

The third line of evidence demonstrating the important roles of alarmins in the development of adaptive immune responses comes from studies using knockout cells or mice with deletion of a given alarmin or its receptor. Necrotic fibroblasts induce inflammatory responses and can activate macrophages and DCs, however, necrotic $\mathrm{Hmgb1}^{-/-}$fibroblasts have significantly lower immunostimulating capacity, pointing to the essential role of HMGB1 in the induction of immune responses $(17,80)$. The alarmin EDN uses TLR2 as its receptor for the activation DCs as well as induction of immune responses $(24,79)$. The capacity of EDN to induce OVA-specific immune responses is greatly compromised in mice with TLR2 deletion, demonstrating the importance of EDN for the induction of adaptive immune response (79). $\mathrm{Hmgn}^{-/-}$mice, in comparison with littermate-matched $\mathrm{HmgnI}^{+/+}$ control, manifest remarkably reduced antigen-specific immune responses, establishing the essential contribution of HMGN1 to the induction of adaptive immunity (82). It has recently been shown that CRAMP promotes mouse DC maturation based on the use of FPR2 (169) and the knockout of either FPR2 or CRAMP not only hamper the maturation of mouse DCs, but also inhibits OVA-specific immune responses in a model of airway inflammation and allergy, solidifying the notion that cathelicidin contributes to the induction of adaptive immune responses $(169,170)$.

Not only do alarmins contribute to the induction of adaptive immune responses, it has gradually become clear that alarmins also participate in determining the types of adaptive immune responses. Human a defensins promote both Th1 and Th2 types of immune response when given together with antigens $(6,7)$. Cathelicidin also enhances both Th1 and Th2 responses $(104,169,170)$. HMGB1 is capable of inducing the generation of protective antitumor immune responses (80), which is known to be dependent on the production of IFN $\gamma$ by Th1 cells and the generation of CTLs. Granulysin promotes OVA specific immune responses with predominant elevation of IFN $\gamma$, but not IL-4 or IL-13, in a TLR4-dependent manner (119). HMGN1 preferentially induces a Th1-polarized immune response, leading to 
the production of TNFa and IFN $\gamma$, but not IL-4, IL-5, or IL-13 (82). S100A8/A9 is also a Th1-promoting alarmin (139). A common property of all the alarmins capable of inducing Th1-type immune responses is their use of TLR4 as a receptor for the activation of DCs to generate IL-12 $(25,80,82,119)$, a cytokine critical for the polarization of Th1 response (171). Therefore, HMGB1, HMGN1, S100A8/A9, and granulysin are Th1-polarizing alarmins. In contrast, two alarmins including EDN and IL-33, have been shown to preferentially promote Th2 type immune responses. EDN induces OVA-specific immune responses characterized by the elevation of IL-4, IL-5, IL-6, IL-10, and IL-13, but not IFN $\gamma$, typical of Th2-polarized immune response (79). Administration of IL-33 to mice induces, in a ST2-dependent manner, elevation of serum IL-5, IL-33, and IgE, as well as eosinophilia and splenomegaly, and airway inflammation, typical of Th2-polarized immune response (172). IL-33 also promotes the production of TSLP another cytokine important for Th2 polarization, in an intestinal mematode infection model (173). IL-33 is crucial for upregulating IL- 5 and IL- 13 by Th2 cells by activating the transcription factor GATA3 (37, 174). Mice lacking either IL-33 or its receptor ST2 show diminished Th2 cytokine production and reduced Th2-polarized immune responses (37, 174-176) Therefore, IL-33 participates in the polarization of Th2 response.

The contribution of various alarmins to the development of Th1 and Th2 dichotomy is likely to be more complex. Recently, it has been shown that certain alarmins can also manifest regulatory roles. Mice lacking the S100A8/A9 expression manifest more severe allergic contact dermatitis in comparison with wild-type mice owing at least in part to accelerated maturation of DCs, suggesting that S100A8/A9 has a regulatory function in adaptive immunity (126). IL-33 is also reported to contribute to the clonal expansion of CTLs in a model of viral infection (177). A number of alarmins including HMGB1 and IL-33 have also been shown to promote wound repair, which apparently requires dampening of immune responses $(30,31,37,38,174)$. Overall, alarmins play important roles in the development of innate/inflammatory and adaptive immune responses.

Given the prominent roles of alarmins in innate/inflammatory and adaptive immune responses, the availability, activity, and signaling of alarmins must be intricately regulated. The best studied example is HMGB1. First, the activities of HMGB1 is regulated by redox states. The reduced form is chemotactic (120), however, breakage of the intramolecular disulfide bond between $\mathrm{Cys}^{23}$ and $\mathrm{Cys}^{45}$ or oxidation of the free thiol group of Cys ${ }^{106}$ to sulfonate destroys its cell-activating activity $(57,120,178)$. It should be mentioned that HMGN1, in contrast, should not be subject to such redox regulation because it lacks Cys residue. Consequently, HMGN1 is not inactivated at inflammatory sites. Second, HMGB1 can bind to CD24, which, through mobilizing Siglec-10 (Siglec-G in mice), counters HMGB1-induced DC activation through TLR4 (179). Third, the N-terminal domain of thrombomodulin can bind to HMGB1 and thrombin to facilitate thrombin-mediated degradation of HMGB1 (180, 181). Finally, T-cell immunoglobulin domain and mucin domain 3 (TIM-3), a checkpoint inhibitor expressed on DCs in tumors, has been shown to bind HMGB1, which functions to prevent HMGB1 from interacting with nucleic acids and hence inhibiting the efficacy of antitumor DNA vaccines or chemotherapy (182). The detailed mechanisms that negatively regulate the availability/activity of other alarmins remain largely undetermined. 


\section{ALARMINS AND TUMOR IMMUNITY}

Tumor formation is accompanied by leukocyte infiltration and innate/inflammatory responses, which leads to either induction of antitumor immunity or promotion of tumor progression and metastasis by fostering tumor growth and concomitant immunosuppression (183). Given their diverse effects on leukocytes and immune system, alarmins can be envisaged to play complex roles in cancer immunity (Table 2).

\section{HMGN1}

HMGN1 preferentially induces Th1-polarized immune responses (82) and has recently been shown to promote the development of protective antitumor immunity $(184,185)$. EG7 mouse thymoma expressing ovalbumin (OVA) as a surrogate tumor-associated antigen (TAA) was found to grow much faster in HMGN1-deficient mice than littermate-matched controls (185). Additionally, HMGN1 $1^{-/}$mice exhibited a higher incidence of spontaneous formation of multiple malignant tumors than their $\mathrm{HMGN} 1^{+/+}$littermates (186). Furthermore, EG7-bearing HMGN1 ${ }^{-/}$mice generated fewer OVA-specific CTLs than EG7bearing $\mathrm{HMGN}^{+/+}$mice, suggesting that HMGN1 contributed to the generation of tumorspecific CTL response and anti-tumor immune protection, a conclusion supported by the fact that HMGN1-expressing EG7 tumors grew more slowly than control EG7 tumors. HMGN1stimulated protective antitumor immunity relied on $\mathrm{T}$ cells because it was abolished by depletion of $\mathrm{CD}^{+}$and $\mathrm{CD} 8^{+} \mathrm{T}$ cells. Mice DNA-vaccinated with a construct directing the expression of HMGN1-gp100 fusion protein indeed induced gp100-specific immune responses and resistant to challenge with mouse B16 melanoma, providing additional support for the crucial role of HMGN1 in the generation of antitumor immunity (185).

\section{HMGB1}

HMGB1 can also promote Th1-polarized immune response and has been implicated in antitumor immune responses $(80,187,188)$. HMGB1 enables the TLR4-dependent activation of dendritic cells, which promotes antigen cross-presentation to CTLs favoring the development of anticancer immune responses in mouse tumor models and human patients (189). In addition, injection of a monoclonal neutralizing antibody specific for HMGB1 abolishes the immunogenicity of anthracycline-treated CT26 or EG7 cells in vivo (190). However, recent studies suggest that HMGB1 can also promote tumor progression, metastasis, and formation of immunosuppressive tumor microenvironment by promoting inflammation $(191,192)$ or interacting with TIM-3 (182). Thus, HMGB1 acts as both a tumor suppressor and an oncogenic factor in tumorigenesis and cancer therapy depending on the context and the study conditions, as well as HMGB1 location and modification as recently reviewed (193).

\section{Defensins}

Human a defensins was shown a long time ago to enhance the antibody response as well as immunoprotection to a syngeneic mouse B cell lymphoma, providing perhaps the earliest hint that alarmin can promote antitumor immune responses (7). Upon delivery by DNA vaccination in the form of defensin-TAA fusion, $\beta$ defensin 2 and 3 promote antitumor immunity toward multiple mouse B-cell lymphomas, in part, through targeting and 
activating DCs $(9,10)$. In addition, mice inoculated with a syngeneic leukemia engineered to express mouse $\beta$-defensin 2 induces the generation of protective antitumor immunity dependent on NK and CD8 T cells (167). Therefore, defensins, at least the ones tested, have the capacity to induce the generation of protective antitumor immune responses. However, it has gradually been shown that a number of human cancers of squamous keratinocytes (e.g. cervical, esophageal, salivary gland, head and neck carcinoma, colon, etc) show elevated expression of $\beta$-defensin 2 and/or 3 (194-199). Both $\beta$-defensin 2 and 3 promotes tumor cell proliferation and/or invasion $(194,197,198)$. $\beta$-defensin 3 upregulation can be triggered by either epidermal growth factor or human papillomavirus (199) and its promotion of tumor cell proliferation involve the activation of NF- $\mathrm{\kappa B}$ (198). In contrast, human $\beta$-defensin 1 has been shown to inhibit the proliferation of several types of cancer cells $(200,201)$. There are 6 a defensins and more than $30 \beta$-defensins in humans (202), and their contributions to tumor immunity require further investigation.

IL-1a

IL-1a, upon synthesis, translocates to the nucleus to function as a transcriptional factor to regulate gene expression $(30,70,142)$. IL-1a is known to inhibit the proliferation of many cancer cells via regulating metabolism, cell cycle, and inducing apoptosis (30, 70, 203-205). Overexpression of IL-1 $a$ on the surface of fibrosarcoma or lymphoma cells promotes their destruction by inducing the generation of protective immunity and memory via promoting the recruitment of macrophages, $\mathrm{NK}$, and $\mathrm{CD}^{+}{ }^{+} \mathrm{T}$ cells into the tumor tissues $(70,206)$. In contrast, IL-1a has also been shown to promote oncogenesis of several types of tumors via enhancing angiogenesis (207), tumor-associated chronic inflammatory response (208), and keratinocyte transformation (209). The non-alarmin, IL-1 $\beta$ has been shown to have only tumor promoting activity. IL-1a can either promote the generation of antitumor immunity or enhance tumor progression $(34,70)$.

IL-33

IL-33 is a nuclear alarmin that primarily induces Th2-polarized immune response, and would be predicted to promote tumor progression by inducing Th2-polarized tumor microenvironment. It seems fitting that IL-33 promotes tumorigenesis by recruiting MCs (210) or enhancing the generation and function of MDSCs (211). IL-33 also facilitates oncogenesis of several types of tumors through promoting epithelial cell proliferation (212, 213 ) and/or transformation $(214,215)$. Surprisingly, overexpression of IL-33 in $4 \mathrm{~T} 1$ and Lewis lung carcinoma cells promotes the generation of antitumor immunity depending on the activation and recruitment of CTL and NK cells $(216,217)$. In addition, IL-33-ST2 axis has antitumor effect on CT26 colon carcinoma since knockdown of ST2 promoted CT26 growth in vivo (218). Furthermore, systemic administration of IL-33 inhibits the growth of established mouse melanoma by promoting DC recruitment and activation in the tumor tissues (219). Thus, IL-33 can ameliorate or promote tumor immunity depending on the context.

\section{HSPs}

Induction of antitumor CTL responses requires TAAs to be transferred to DCs for crosspresentation (220). HSPs such as HSP70, HSP90, gp96, and calreticulin are critical for TAA 
cross-presentation using CD91 as the receptor (220-223). In addition, purified HSPs stimulate DC maturation (86-90) and generation of Th1-polarized antitumor immunity (88, 90, 220, 224). Furthermore, it has recently been shown that exogenous HSP70 triggers the secretion of endogenous HSP70 to tumor cell surface, which sensitizes cancer cells for CTLmediated killing (225). Therefore, HSPs are primarily alarmins that promote the generation of protective antitumor immunity. In fact, autologous tumor-derived HSPs [e.g. HSP96peptide complex (HSPPC-96), HSPPC-70, etc) have been evaluated as tumor vaccines in a variety of phase I-III trials over a wide range of cancers, with clinical benefit in some melanoma patients (226).

\section{ATP}

ATP induces DC maturation $(91,92)$ and inflammasome activation $(94,95,98)$ and consequently promotes the generation of antitumor immunity (94). This is supported by a recent report showing that knockout of $\mathrm{P} 2 \mathrm{X} 7$ in mice, the major receptor mediating the effect of ATP on the activation of DCs and inflammasome $(32,92,94,95)$, reduces antitumor immunity and accelerates the progression of B16 melanoma and CT26 colon carcinoma (227). However, ATP upon release into extracellular space is rapidly converted into adenosine, a well-established immunosuppressor (228-230) and oncogenic promoter (230). Indeed, blockade of A2A, one the four adenosine receptors, or knockout of CD73, an ecto- $5^{\prime}$-nucleotidase critical for the conversion of ATP to adenosine, promotes antitumor immunity based on IFN $\gamma$, NK cells, and CTLs, and inhibit oncogenesis, tumor growth, and metastasis (231-233).

\section{S100 proteins}

S100A8/A9 induces apoptosis of diverse types of human and mouse tumor cell lines via $\mathrm{Zn}^{2+}$ chelation and induction of reactive oxygen species $(234,235)$. Together with its DCactivating activity, S100A8/A9 may play a role in tumor immunity. However, S100A8/A9 promotes tumor growth by inhibit the differentiation of DCs and macrophages and enhance MDSC production, recruitment and infiltration (236, 237). S100A9-deficient (also lacking S100A8 expression) mice generates potent antitumor immune responses to reject implanted tumors (237). S100A8/A9 produced by lung phagocytes in response to tumors promotes MDSC recruitment by inducing serum amyloid protein A3, which facilitates metastasis of Lewis lung carcinoma and B16 melanoma into the lung. Overall, S100 A8/A9 appear to suppress the generation of antitumor immunity.

The roles of alarmins in tumor immunity are very complicated, primarily depending on their receptor usage and effects on non-leukocytes and leukocytes. HMGB1 primarily promotes the generation of antitumor immunity by signaling through TLR4 $(189,190)$, however, it predominantly promote tumor progression by interacting with RAGE (238) or TIM-3 (182). For $\beta$ defensins, they differentially regulate the proliferation of oral squamous cell carcinoma and prostate cancer cells and therefore might function as proto-oncogene or as a tumor suppressor in those tumors $(239,240)$. All alarmins participate in the initiation of innate/inflammatory immune responses and their effects on cancer immunity depend largely on the balance of inducing protective immune responses versus fostering immunosuppression. Overall, alarmins preferentially promote Th1-polarized immune 
responses mediate antitumor immunity, whereas alarmins enhance the recruitment of immunosuppressive MDSCs or Tregs may contribute to tumor growth.

Given the critical roles of NK, CTL, and IFN $\gamma$ in protective immunity against cancers, Th1polarizing alarmins (e.g. HMGB1, HMGN1, and HSPs, etc) are potentially good candidates to be used for designing immunotherapies for cancers. Based on the critical roles of HMGN1 in the development of protective antitumor immunity $(184,185)$, we further investigated whether HMGN1 could be harnessed for the treatment of growing tumors in a therapeutic vaccination approach. We have developed a therapeutic 'cocktail' (termed 'TheraVac') consisting of HMGN1, the TLR7/8 ligand R848, and an inhibitor of immunosuppression (e.g. Cytoxan, anti-CTLA-4, or anti-PD-L1). HMGN1 and R848 synergized in activating DCs to produce IL-12 (Nie, et al., submitted). TheraVac cured a number of large ( $\geq 1 \mathrm{~cm}$ in diameter) established tumors, namely CT26 (colon), Renca (kidney), EG7 (thymoma), and Hepa1-6 (hepatoma) in mice. Treatment with TheraVac resulted in augmented infiltration of effector T cells into the tumor tissue (Han, et al., in press and Nie, et al., submitted). The cured mice showed specific protective antitumor immunity. This therapeutic regimen also caused migration of tumor-infiltrating dendritic cells from tumors to home to draining lymph nodes (Nie, et al., submitted). Hepa1-6-bearing mice treated with TheraVac, generated increased Hepa1-6-specific CTLs in the draining lymph nodes and showed greatly upregulated expression of CXCL9, CXCL10, and IFN- $\gamma$ and elevated infiltration of T lymphocytes in tumor tissues (Han, et al., in press). The successful use of HMGN1 in TheraVac to cure large tumors with the genearation of longterm memory further solidify the idea that HMGN1 predominantly promotes the generation of protective antitumor immunity.

\section{CONCLUSIONS AND PERSPECTIVES}

Alarmins are multifunctional endogenous molecules that are sensed by host immune system and contribute to host defense. Since they are constitutively available they are first reactors to infectious and traumatic insults. Based on their chemotactic leukocyte-recruiting and DCactivating capacities, they initiate not only innate but also adaptive immune responses. The key ability of alarmins to activate DC to mature enables these cells to migrate and deliver their antigenic contents to the T lymphocytes in draining lymph nodes resulting in the adaptive immunity and $\mathrm{T}$ cell dependent long term immune memory. Since preformed alarmins can be found bound to cell chromatin, in cell granules, vesicles, and even the cytosol, any nucleated cell can be a source. Alarmins are released by dead and dying cells and in response to a variety of inflammatory stimulants. Alarmins target not only chemotactic GiPCR, but a variety of activating receptors expressed by many cell types. Thus, alarmins are ubiquitous warning signals.

As previously indicated we propose that numerous molecules with alarmin activities remain to be identified. Some of them are well known markers/promulgators inflammation. One or more of the classical proinflammatory "acute phase proteins" are probably alarmins. For example, serum amyloid A (SAA) is chemotactic for dendritic cells and other leucocytes (241) and also activates DCs (242), and can therefore be considered an alarmin. Similarly, some components generated by the complement cascade such as C3a and C5a have both 
chemotactic (243) and activating (244) effects on leucocytes and are therefore likely to be alarmins. These considerations enable us to expand and redefine our view of some wellknown proinflammatory intercellular signals. These age-old alarmins together with our identification of a-synuclein, a product of nerve cells, a novel alarmin conveys the message that a broad array of molecules engages in this means of host defense. Of course one may ask what can you do with this information? Hopefully, identification of the receptors and downstream signal transducers of alarmins may lead to the identification of antagonistic inhibitors and agonists, with the capacity to modulate alarmins and potential therapeutic applicability.

\section{Acknowledgments}

This research was supported in part by the Intramural Research Program of NIH, Frederick National Lab, Center for Cancer Research, Cancer and Inflammation Program. The content of this publication does not necessarily reflect the views or policies of the Department of Health and Human Services, nor does mention of trade names, commercial products, or organizations imply endorsement by the U.S. Government. The publisher or recipient acknowledges right of the U.S. Government to retain a nonexclusive, royalty-free license in and to any copyright covering the article.

The authors thank Ms. Sharon Livingstone for her excellent managerial assistance in preparing this manuscript.

\section{References}

1. Oppenheim JJ, Yang D. Alarmins: chemotactic activators of immune responses. Curr Opin Immunol. 2005; 17:359-365. [PubMed: 15955682]

2. Matzinger P. Tolerance, danger, and the extended family. Annu Rev Immunol. 1994; 12:991-1045. [PubMed: 8011301]

3. Gallucci S, Matzinger P. Danger signals: SOS to the immune system. Curr Opin Immunol. 2001; 13:114-119. [PubMed: 11154927]

4. Chertov O, Michiel DF, Xu L, et al. Identification of defensin-1, defensin-2, and CAP37/azurocidin as T-cell chemoattractant proteins released from interleukin-8-stimulated neutrophils. J Biol Chem. 1996; 271:2935-2940. [PubMed: 8621683]

5. Ganz T, Selsted ME, Szklarek D, et al. Defensins: Natural peptide antibiotics of human neutrophils. J Clin Invest. 1985; 76:1427-1435. [PubMed: 2997278]

6. Lillard JW Jr, Boyaka PN, Chertov O, Oppenheim JJ, McGhee JR. Mechanisms for induction of acquired host immunity by neutrophil peptide defensins. Proc Natl Acad Sci USA. 1999; 96:651656. [PubMed: 9892688]

7. Tani K, Murphy WJ, Chertov O, et al. Defensins act as potent adjuvants that promote cellular and humoral immune responses in mice to a lymphoma idiotype and carrier antigens. Int Immunol. 2000; 12:691-700. [PubMed: 10784615]

8. Yang D, Chertov O, Bykovskaia SN, et al. b-Defensins: Linking innate and adaptive immunity through dendritic and T cell CCR6. Science. 1999; 286:525-528. [PubMed: 10521347]

9. Biragyn A, Surenhu M, Yang D, et al. Mediators of innate immunity that target immature, but not mature, dendritic cells induce antitumor immunity when genetically fused with nonimmunogenic tumor antigens. J Immunol. 2001; 167:6644-6653. [PubMed: 11714836]

10. Biragyn A, Ruffini PA, Leifer CA, et al. Toll-like receptor 4-dependent activation of dendritic cells by b-defensin 2. Science. 2002; 298:1025-1029. [PubMed: 12411706]

11. Yang D, Chen Q, Chertov O, Oppenheim JJ. Human neutrophil defensins selectively chemoattract naïve T and immature dendritic cells. J Leukoc Biol. 2000; 68:9-14. [PubMed: 10914484]

12. Yang D, Chen Q, Schmidt AP, et al. LL-37, the neutrophil granule- and epithelial cell-derived cathelicidin, utilizes formyl peptide receptor-like 1 (FPRL1) as a receptor to chemoattract human peripheral blood neutrophils, monocytes, and T cells. J Exp Med. 2000; 192:1069-1074.

[PubMed: 11015447] 
13. Andersson U, Wang H, Palmblad K, et al. High mobility group 1 protein (HMG-1) stimulates proinflammatory cytokine synthesis in human monocytes. J Exp Med. 2000; 192:565-570. [PubMed: 10952726]

14. Niyonsaba F, Someya A, Hirata M, Ogawa H, Nagaoka I. Evaluation of the effects of peptide antibiotics human b-defensin-1/2 and LL-37 on histamine release and prostaglandin $\mathrm{D}_{2}$ production from mast cells. Eur J Immunol. 2001; 31:1066-1075. [PubMed: 11298331]

15. Chaly YV, Paleolog EM, Kolesnikova TS, Tikhonov II, Petratchenko EV, Voitenok NN. Neutrophil a-defensin human neutrophil peptide modulates cytokine production in human monocytes and adhesion molecule expression in endothelial cells. Eur Cytokine Netw. 2000; 11:257-260. [PubMed: 10903805]

16. Scott MG, Davidson DJ, Gold MR, Bowdish D, Hancock REW. The human antimicrobial peptide LL-37 is a multifunctional modulator of innate immune response. J Immunol. 2002; 169:38833891. [PubMed: 12244186]

17. Scaffidi P, Misteli T, Bianchi ME. Release of chromatin protein HMGB1 by necrotic cells triggers inflammation. Nature. 2002; 418:191-195. [PubMed: 12110890]

18. Davidson DJ, Currie AJ, Reid GS, et al. The cationic antimicrobial peptide LL-37 modulates dendritic cell differentiation and dendritic cell-induced T cell polarization. J Immunol. 2004; 172:1146-1156. [PubMed: 14707090]

19. Bowdish DM, Davidson DJ, Speert DP, Hancock RE. The human cationic peptide LL-37 induces activation of the extracellular signal-regulated kinase and p38 kinase pathways in primary human monocytes. J Immunol. 2004; 172:3758-3765. [PubMed: 15004180]

20. Yang D, Rosenberg HF, Chen Q, Dyer KD, Kurosaka K, Oppenheim JJ. Eosinophil-derived neurotoxin (EDN), an antimicrobial protein with chemotactic activities for dendritic cells. Blood. 2003; 102:3396-3403. [PubMed: 12855582]

21. Park JS, Arcaroli J, Yum HK, et al. Activation of gene expression in human neutrophils by high mobility group box 1 protein. Am J Physiol Cell Physiol. 2003; 284:C870-879. [PubMed: 12620891]

22. Li J, Kokkola R, Tabibzadeh S, et al. Structural basis for the proinflammatory cytokine activity of high mobility group box 1. Mol Med. 2003; 9:37-45. [PubMed: 12765338]

23. Yang H, Ochani M, Li J, et al. Reversing established sepsis with antagonists of endogenous highmobility group box 1. Proc Natl Acad Sci U S A. 2004; 101:296-301. [PubMed: 14695889]

24. Yang D, Chen Q, Rosenberg HF, et al. Human ribonuclease A superfamily members, eosinophilderived neurotoxin and pancreatic ribonuclease, induce dendritic cell maturation and activation. $\mathrm{J}$ Immunol. 2004; 173:6134-6142. [PubMed: 15528350]

25. Messmer D, Yang H, Telusma G, et al. High mobility group box protein 1: an endogenous signal for dendritic cell maturation and Th1 polarization. J Immunol. 2004; 173:307-313. [PubMed: 15210788]

26. Yang D, Biragyn A, Hoover DM, Lubkowski J, Oppenheim JJ. Multiple roles of antimicrobial defensins, cathelicidins, and eosinophil-derived neurotoxin in host defense. Annu Rev Immunol. 2004; 22:181-315. [PubMed: 15032578]

27. Yang D, Oppenheim JJ. Antimicrobial proteins act as "alarmins" in joint immune defense. Arthritis Rheum. 2004; 50:3401-3403. [PubMed: 15529365]

28. Nathan C. Points of control in inflammation. Nature. 2002; 420:846-852. [PubMed: 12490957]

29. Chen GY, Nunez G. Sterile inflammation: sensing and reacting to damage. Nat Rev Immunol. 2010; 10:826-837. [PubMed: 21088683]

30. Arend WP, Palmer G, Gabay C. IL-1, IL-18, and IL-33 families of cytokines. Immunol Rev. 2008; 223:20-38. [PubMed: 18613828]

31. Bianchi ME. DAMPs, PAMPs and alarmins: all we need to know about danger. J Leukoc Biol. 2007; 81:1-5.

32. Yang D, Wei F, Tewary P, Howard OM, Oppenheim JJ. Alarmin-induced cell migration. European journal of immunology. 2013; 43:1412-1418. [PubMed: 23619968]

33. Lotze MT, Tracey KJ. High-mobility group box 1 protein (HMGB1): nuclear weapon in the immune arsenal. Nat Rev Immunol. 2005; 5:331-342. [PubMed: 15803152] 
34. Cohen I, Rider P, Carmi Y, et al. Differential release of chromatin-bound IL-1alpha discriminates between necrotic and apoptotic cell death by the ability to induce sterile inflammation. Proc Natl Acad Sci U S A. 2010; 107:2574-2579. [PubMed: 20133797]

35. Pisetsky DS, Erlandsson-Harris H, Andersson U. High-mobility group box protein 1 (HMGB1): an alarmin mediating the pathogenesis of rheumatic disease. Arthritis Res Ther. 2008; 10:209. [PubMed: 18598385]

36. Chan JK, Roth J, Oppenheim JJ, et al. Alarmins: awaiting a clinical response. J Clin Invest. 2012; 122:2711-2719. [PubMed: 22850880]

37. Martin NT, Martin MU. Interleukin 33 is a guardian of barriers and a local alarmin. Nat Immunol. 2016; 17:122-131. [PubMed: 26784265]

38. Bertheloot D, Latz E. HMGB1, IL-1alpha, IL-33 and S100 proteins: dual-function alarmins. Cell Mol Immunol. 2017; 14:43-64. [PubMed: 27569562]

39. Stolzenberg E, Berry D, Yang D, et al. A role for neuronal alpha synuclein in gastrointestinal immunity. Journal of Innate Immunity. Accepted.

40. Befus AD, Mowat C, Gilchrist M, Hu J, Solomon S, Bateman A. Neutrophil defensins induce histamine secretion from mast cells: mechanisms of action. J Immunol. 1999; 163:947-953. [PubMed: 10395691]

41. Yamashita T, Saito K. Purification, primary structure, and biological activity of guinea pig neutrophil cationic peptides. Infect Immun. 1989; 57:2405-2409. [PubMed: 2473036]

42. Chen X, Niyonsaba F, Ushio H, et al. Antimicrobial peptides human beta-defensin (hBD)-3 and hBD-4 activate mast cells and increase skin vascular permeability. Eur J Immunol. 2007; 37:434444. [PubMed: 17230440]

43. Gupta K, Kotian A, Subramanian H, Daniell H, Ali H. Activation of human mast cells by retrocyclin and protegrin highlight their immunomodulatory and antimicrobial properties. Oncotarget. 2015; 6:28573-28587. [PubMed: 26378047]

44. Subramanian H, Gupta K, Guo Q, Price R, Ali H. Mas-related gene X2 (MrgX2) is a novel G protein-coupled receptor for the antimicrobial peptide LL-37 in human mast cells: resistance to receptor phosphorylation, desensitization, and internalization. J Biol Chem. 2011; 286:4473944749. [PubMed: 22069323]

45. Allakhverdi Z, Smith DE, Comeau MR, Delespesse G. Cutting edge: The ST2 ligand IL-33 potently activates and drives maturation of human mast cells. J Immunol. 2007; 179:2051-2054. [PubMed: 17675461]

46. Pushparaj PN, Tay HK, H’Ng SC, et al. The cytokine interleukin-33 mediates anaphylactic shock. Proc Natl Acad Sci U S A. 2009; 106:9773-9778. [PubMed: 19506243]

47. Bulanova E, Budagian V, Orinska Z, Koch-Nolte F, Haag F, Bulfone-Paus S. ATP induces P2X7 receptor-independent cytokine and chemokine expression through $\mathrm{P} 2 \mathrm{X} 1$ and $\mathrm{P} 2 \mathrm{X} 3$ receptors in murine mast cells. J Leukoc Biol. 2009; 85:692-702. [PubMed: 19164130]

48. Kurashima Y, Amiya T, Nochi T, et al. Extracellular ATP mediates mast cell-dependent intestinal inflammation through P2X7 purinoceptors. Nat Commun. 2012; 3:1034. [PubMed: 22948816]

49. Getting SJ, Flower RJ, Parente L, et al. Molecular determinants of monosodium urate crystalinduced murine peritonitis: a role for endogenous mast cells and a distinct requirement for endothelial-derived selectins. J Pharmacol Exp Ther. 1997; 283:123-130. [PubMed: 9336316]

50. Hsu DZ, Chu PY, Chen SJ, Liu MY. Mast Cell Stabilizer Ketotifen Inhibits Gouty Inflammation in Rats. Am J Ther. 2016; 23:e1009-1015. [PubMed: 23884077]

51. Wang H, Bloom O, Zhang M, et al. HMG-1 as a late mediator of endotoxin lethality in mice. Science. 1999; 285:248-251. [PubMed: 10398600]

52. Chen Q, Jin Y, Zhang K, et al. Alarmin HNP-1 promotes pyroptosis and IL-1beta release through different roles of NLRP3 inflammasome via P2X7 in LPS-primed macrophages. Innate Immun. 2014; 20:290-300. [PubMed: 23792296]

53. Petrov V, Funderburg N, Weinberg A, Sieg S. Human beta defensin-3 induces chemokines from monocytes and macrophages: diminished activity in cells from HIV-infected persons. Immunology. 2013; 140:413-420. [PubMed: 23829433] 
54. Elssner A, Duncan M, Gavrilin M, Wewers MD. A novel P2X7 receptor activator, the human cathelicidin-derived peptide LL37, induces IL-1b processing and release. J Immunol. 2004; 172:4987-4994. [PubMed: 15067080]

55. Nagaoka I, Tamura H, Hirata M. An antimicrobial cathelicidin peptide, human CAP18/LL-37, suppresses neutrophil apoptosis via the activation of formyl-peptide receptor-like 1 and P2X7. J Immunol. 2006; 176:3044-3052. [PubMed: 16493063]

56. Kokkola R, Andersson A, Mullins G, et al. RAGE is the major receptor for the proinflammatory activity of HMGB1 in rodent macrophages. Scand J Immunol. 2005; 61:1-9. [PubMed: 15644117]

57. Yang H, Hreggvidsdottir HS, Palmblad K, et al. A critical cysteine is required for HMGB1 binding to Toll-like receptor 4 and activation of macrophage cytokine release. Proc Natl Acad Sci U S A. 2010; 107:11942-11947. [PubMed: 20547845]

58. Su Z, Zhang P, Yu Y, et al. HMGB1 Facilitated Macrophage Reprogramming towards a Proinflammatory M1-like Phenotype in Experimental Autoimmune Myocarditis Development. Scientific reports. 2016; 6:21884. [PubMed: 26899795]

59. Galloway E, Shin T, Huber N, et al. Activation of hepatocytes by extracellular heat shock protein 72. Am J Physiol Cell Physiol. 2008; 295:C514-520. [PubMed: 18508912]

60. Quintana FJ, Cohen IR. Heat shock proteins as endogenous adjuvants in sterile and septic inflammation. J Immunol. 2005; 175:2777-2782. [PubMed: 16116161]

61. Mookherjee N, Hamill P, Gardy J, et al. Systems biology evaluation of immune responses induced by human host defence peptide LL-37 in mononuclear cells. Mol Biosyst. 2009; 5:483-496. [PubMed: 19381363]

62. Ohashi K, Burkart V, Flohe S, Kolb H. Cutting Edge: Heat Shock Protein 60 Is a Putative Endogenous Ligand of the Toll-Like Receptor-4 Complex. J Immunol. 2000; 164:558-561. [PubMed: 10623794]

63. Deng A, Chen S, Li Q, Lyu SC, Clayberger C, Krensky AM. Granulysin, a cytolytic molecule, is also a chemoattractant and proinflammatory activator. J Immunol. 2005; 174:5243-5248. [PubMed: 15843520]

64. Sunahori K, Yamamura M, Yamana J, et al. The S100A8/A9 heterodimer amplifies proinflammatory cytokine production by macrophages via activation of nuclear factor kappa B and p38 mitogen-activated protein kinase in rheumatoid arthritis. Arthritis Res Ther. 2006; 8:R69. [PubMed: 16613612]

65. Zheng Y, Niyonsaba F, Ushio H, et al. Microbicidal protein psoriasin is a multifunctional modulator of neutrophil activation. Immunology. 2008; 124:357-367. [PubMed: 18194266]

66. Vogl T, Tenbrock K, Ludwig S, et al. Mrp8 and Mrp14 are endogenous activators of Toll-like receptor 4, promoting lethal, endotoxin-induced shock. Nat Med. 2007; 13:1042-1049. [PubMed: 17767165]

67. Kono H, Rock KL. How dying cells alert the immune system to danger. Nat Rev Immunol. 2008; 8:279-289. [PubMed: 18340345]

68. Kurowska-Stolarska M, Stolarski B, Kewin P, et al. IL-33 amplifies the polarization of alternatively activated macrophages that contribute to airway inflammation. J Immunol. 2009; 183:6469-6477. [PubMed: 19841166]

69. Nelson MP, Christmann BS, Werner JL, et al. IL-33 and M2a alveolar macrophages promote lung defense against the atypical fungal pathogen Pneumocystis murina. J Immunol. 2011; 186:23722381. [PubMed: 21220696]

70. Dinarello CA. Immunological and inflammatory functions of the interleukin-1 family. Annu Rev Immunol. 2009; 27:519-550. [PubMed: 19302047]

71. Presicce P, Giannelli S, Taddeo A, Villa ML, Della Bella S. Human defensins activate monocytederived dendritic cells, promote the production of proinflammatory cytokines, and up-regulate the surface expression of CD91. J Leukoc Biol. 2009; 86:941-948. [PubMed: 19477909]

72. Tewary P, de la Rosa G, Sharma N, et al. beta-Defensin 2 and 3 promote the uptake of self or CpG DNA, enhance IFN-alpha production by human plasmacytoid dendritic cells, and promote inflammation. Journal of immunology. 2013; 191:865-874. 
73. Ferris LK, Mburu YK, Mathers AR, et al. Human beta-defensin 3 induces maturation of human langerhans cell-like dendritic cells: an antimicrobial peptide that functions as an endogenous adjuvant. J Invest Dermatol. 2013; 133:460-468. [PubMed: 22951718]

74. Sweeney CM, Russell SE, Malara A, et al. Human ss-Defensin 3 and Its Mouse Ortholog Murine ss-Defensin 14 Activate Langerhans Cells and Exacerbate Psoriasis-Like Skin Inflammation in Mice. J Invest Dermatol. 2016; 136:723-727. [PubMed: 27015459]

75. Wang F, Qiao L, Lv X, et al. Alarmin human alpha defensin HNP1 activates plasmacytoid dendritic cells by triggering NF-kappaB and IRF1 signaling pathways. Cytokine. 2016; 83:53-60. [PubMed: 27031443]

76. Bandholtz L, Ekman GJ, Vilhelmsson M, et al. Antimicrobial peptide LL-37 internalized by immature human dendritic cells alters their phenotype. Scand J Immunol. 2006; 63:410-419. [PubMed: 16764694]

77. Lande R, Gregorio J, Facchinetti V, et al. Plasmacytoid dendritic cells sense self-DNA coupled with antimicrobial peptide. Nature. 2007; 449:564-569. [PubMed: 17873860]

78. Ganguly D, Chamilos G, Lande R, et al. Self-RNA-antimicrobial peptide complexes activate human dendritic cells through TLR7 and TLR8. J Exp Med. 2009; 206:1983-1994. [PubMed: 19703986]

79. Yang D, Chen Q, Su SB, et al. Eosinophil-derived neurotoxin acts as an alarmin to activate the TLR2-MyD88 signal pathway in dendritic cells and enhances Th2 immune responses. J Exp Med. 2008; 205:79-90. [PubMed: 18195069]

80. Rovere-Querini P, Capobianco A, Scaffidi P, et al. HMGB1 is an endogenous immune adjuvant released by necrotic cells. EMBO Rep. 2004; 5:825-830. [PubMed: 15272298]

81. Yang D, Chen Q, Yang H, Tracey KJ, Bustin M, Oppenheim JJ. High mobility group box-1 protein induces the migration and activation of human dendritic cells and acts as an alarmin. J Leukoc Biol. 2007; 81:59-66. [PubMed: 16966386]

82. Yang D, Postnikov YV, Li Y, et al. High-mobility group nucleosome-binding protein 1 acts as an alarmin and is critical for lipopolysaccharide-induced immune responses. J Exp Med. 2012; 209:157-171. [PubMed: 22184635]

83. Ivanov S, Dragoi AM, Wang X, et al. A novel role for HMGB1 in TLR9-mediated inflammatory responses to CpG-DNA. Blood. 2007; 110:1970-1981. [PubMed: 17548579]

84. Tian J, Avalos AM, Mao SY, et al. Toll-like receptor 9-dependent activation by DNA-containing immune complexes is mediated by HMGB1 and RAGE. Nat Immunol. 2007; 8:487-496. [PubMed: 17417641]

85. Petersen B, Wolf M, Austermann J, et al. The alarmin Mrp8/14 as regulator of the adaptive immune response during allergic contact dermatitis. EMBO J. 2013; 32:100-111. [PubMed: 23188082]

86. Singh-Jasuja H, Scherer HU, Hilf N, et al. The heat shock protein gp96 induces maturation of dendritic cells and down-regulation of its receptor. Eur J Immunol. 2000; 30:2211-2215. [PubMed: 10940912]

87. Wang Y, Kelly CG, Singh M, et al. Stimulation of Th1-polarizing cytokines, C-C chemokines, maturation of dendritic cells, and adjuvant function by the peptide binding fragment of heat shock protein 70. J Immunol. 2002; 169:2422-2429. [PubMed: 12193710]

88. Chen T, Guo J, Han C, Yang M, Cao X. Heat shock protein 70, released from heat-stressed tumor cells, initiates antitumor immunity by inducing tumor cell chemokine production and activating dendritic cells via TLR4 pathway. J Immunol. 2009; 182:1449-1459. [PubMed: 19155492]

89. Flohe SB, Bruggemann J, Lendemans S, et al. Human heat shock protein 60 induces maturation of dendritic cells versus a Th1-promoting phenotype. J Immunol. 2003; 170:2340-2348. [PubMed: 12594256]

90. Zheng H, Dai J, Stoilova D, Li Z. Cell surface targeting of heat shock protein gp96 induces dendritic cell maturation and antitumor immunity. J Immunol. 2001; 167:6731-6735. [PubMed: 11739487]

91. Wilkin F, Duhant X, Bruyns C, Suarez-Huerta N, Boeynaems JM, Robaye B. The P2Y11 receptor mediates the ATP-induced maturation of human monocyte-derived dendritic cells. J Immunol. 2001; 166:7172-7177. [PubMed: 11390464] 
92. Schnurr M, Then F, Galambos P, et al. Extracellular ATP and TNF-alpha synergize in the activation and maturation of human dendritic cells. J Immunol. 2000; 165:4704-4709. [PubMed: 11035114]

93. Shi Y, Evans JE, Rock KL. Molecular identification of a danger signal that alerts the immune system to dying cells. Nature. 2003; 425:516-521. [PubMed: 14520412]

94. Ghiringhelli F, Apetoh L, Tesniere A, et al. Activation of the NLRP3 inflammasome in dendritic cells induces IL-1beta-dependent adaptive immunity against tumors. Nat Med. 2009; 15:11701178. [PubMed: 19767732]

95. Strowig T, Henao-Mejia J, Elinav E, Flavell R. Inflammasomes in health and disease. Nature. 2012; 481:278-286. [PubMed: 22258606]

96. Martinon F, Petrilli V, Mayor A, Tardivel A, Tschopp J. Gout-associated uric acid crystals activate the NALP3 inflammasome. Nature. 2006; 440:237-241. [PubMed: 16407889]

97. Weber MD, Frank MG, Tracey KJ, Watkins LR, Maier SF. Stress induces the danger-associated molecular pattern HMGB-1 in the hippocampus of male Sprague Dawley rats: a priming stimulus of microglia and the NLRP3 inflammasome. J Neurosci. 2015; 35:316-324. [PubMed: 25568124]

98. Iyer SS, Pulskens WP, Sadler JJ, et al. Necrotic cells trigger a sterile inflammatory response through the Nlrp3 inflammasome. Proc Natl Acad Sci U S A. 2009; 106:20388-20393. [PubMed: 19918053]

99. Willingham SB, Allen IC, Bergstralh DT, et al. NLRP3 (NALP3, Cryopyrin) facilitates in vivo caspase-1 activation, necrosis, and HMGB1 release via inflammasome-dependent and independent pathways. J Immunol. 2009; 183:2008-2015. [PubMed: 19587006]

100. Niyonsaba F, Iwabuchi K, Matsuda H, Ogawa H, Nagaoka I. Epithelial cell-derived human bdefensin-2 acts as a chemotaxin for mast cells through a pertussis toxin-sensitive and phospholipase C-dependent pathway. Int Immunol. 2002; 14:421-426. [PubMed: 11934878]

101. Cuesta A, Meseguer J, Esteban MA. Molecular and functional characterization of the gilthead seabream beta-defensin demonstrate its chemotactic and antimicrobial activity. Mol Immunol. 2011; 48:1432-1438. [PubMed: 21497909]

102. Hubert P, Herman L, Maillard C, et al. Defensins induce the recruitment of dendritic cells in cervical human papillomavirus-associated (pre)neoplastic lesions formed in vitro and transplanted in vivo. FASEB J. 2007; 21:2765-2775. [PubMed: 17470569]

103. Niyonsaba F, Iwabuchi K, Someya A, et al. A cathelicidin family of human antibacterial peptide LL-37 induces mast cell chemotaxis. Immunology. 2002; 106:20-26. [PubMed: 11972628]

104. Kurosaka K, Chen Q, Yarovinsky F, Oppenheim JJ, Yang D. Mouse cathelin-related antimicrobial peptide chemoattracts leukocytes using formyl peptide receptor-like $1 /$ mouse formyl peptide receptor-like 2 as the receptor and acts as an immune adjuvant. J Immunol. 2005; 174:62576265. [PubMed: 15879124]

105. Gastpar R, Gross C, Rossbacher L, Ellwart J, Riegger J, Multhoff G. The cell surface-localized heat shock protein 70 epitope TKD induces migration and cytolytic activity selectively in human NK cells. J Immunol. 2004; 172:972-980. [PubMed: 14707070]

106. Ryckman C, Vandal K, Rouleau P, Talbot M, Tessier PA. Proinflammatory activities of S100: proteins S100A8, S100A9, and S100A8/A9 induce neutrophil chemotaxis and adhesion. J Immunol. 2003; 170:3233-3242. [PubMed: 12626582]

107. Yan WX, Armishaw C, Goyette J, et al. Mast cell and monocyte recruitment by S100A12 and its hinge domain. J Biol Chem. 2008; 283:13035-13043. [PubMed: 18292089]

108. Wolf R, Howard OM, Dong HF, et al. Chemotactic Activity of S100A7 (Psoriasin) Is Mediated by the Receptor for Advanced Glycation End Products and Potentiates Inflammation with Highly Homologous but Functionally Distinct S100A15. J Immunol. 2008; 181:1499-1506. [PubMed: 18606705]

109. Cornish CJ, Devery JM, Poronnik P, Lackmann M, Cook DI, Geczy CL. S100 protein CP-10 stimulates myeloid cell chemotaxis without activation. J Cell Physiol. 1996; 166:427-437. [PubMed: 8592003]

110. Berthelot F, Fattoum L, Casulli S, Gozlan J, Marechal V, Elbim C. The effect of HMGB1, a damage-associated molecular pattern molecule, on polymorphonuclear neutrophil migration depends on its concentration. J Innate Immun. 2012; 4:41-58. [PubMed: 21860212] 
111. Rouhiainen A, Kuja-Panula J, Wilkman E, et al. Regulation of monocyte migration by amphoterin (HMGB1). Blood. 2004; 104:1174-1182. [PubMed: 15130941]

112. Komai-Koma M, Xu D, Li Y, McKenzie AN, McInnes IB, Liew FY. IL-33 is a chemoattractant for human Th2 cells. Eur J Immunol. 2007; 37:2779-2786. [PubMed: 17853410]

113. Verri WA Jr, Souto FO, Vieira SM, et al. IL-33 induces neutrophil migration in rheumatoid arthritis and is a target of anti-TNF therapy. Ann Rheum Dis. 2010; 69:1697-1703. [PubMed: 20472598]

114. Alves-Filho JC, Sonego F, Souto FO, et al. Interleukin-33 attenuates sepsis by enhancing neutrophil influx to the site of infection. Nat Med. 2010; 16:708-712. [PubMed: 20473304]

115. Kobayashi T, Kouzaki H, Kita H. Human eosinophils recognize endogenous danger signal crystalline uric acid and produce proinflammatory cytokines mediated by autocrine ATP. J Immunol. 2010; 184:6350-6358. [PubMed: 20483787]

116. Corriden R, Insel PA. New insights regarding the regulation of chemotaxis by nucleotides, adenosine, and their receptors. Purinergic Signal. 2012; 8:587-598. [PubMed: 22528684]

117. Allen SJ, Crown SE, Handel TM. Chemokine: receptor structure, interactions, and antagonism. Annu Rev Immunol. 2007; 25:787-820. [PubMed: 17291188]

118. Germain RN, Robey EA, Cahalan MD. A decade of imaging cellular motility and interaction dynamics in the immune system. Science. 2012; 336:1676-1681. [PubMed: 22745423]

119. Tewary P, Yang D, de la Rosa G, et al. Granulysin activates antigen-presenting cells through TLR4 and acts as an immune alarmin. Blood. 2010; 116:3465-3474. [PubMed: 20660289]

120. Venereau E, Casalgrandi M, Schiraldi M, et al. Mutually exclusive redox forms of HMGB1 promote cell recruitment or proinflammatory cytokine release. J Exp Med. 2012; 209:1519-1528. [PubMed: 22869893]

121. Schiraldi M, Raucci A, Munoz LM, et al. HMGB1 promotes recruitment of inflammatory cells to damaged tissues by forming a complex with CXCL12 and signaling via CXCR4. The Journal of experimental medicine. 2012; 209:551-563. [PubMed: 22370717]

122. Conejo-Garcia JR, Benencia F, Courreges MC, et al. Tumor-infiltrating dendritic cell precursors recruited by a b-defensin contribute to vasculogenesis under the influence of Vegf-A. Nat Med. 2004; 10:950-958. [PubMed: 15334073]

123. Ley K, Laudanna C, Cybulsky MI, Nourshargh S. Getting to the site of inflammation: the leukocyte adhesion cascade updated. Nat Rev Immunol. 2007; 7:678-689. [PubMed: 17717539]

124. Chavakis E, Hain A, Vinci M, et al. High-mobility group box 1 activates integrin-dependent homing of endothelial progenitor cells. Circ Res. 2007; 100:204-212. [PubMed: 17218606]

125. Ghannam S, Dejou C, Pedretti N, et al. CCL20 and beta-defensin-2 induce arrest of human Th17 cells on inflamed endothelium in vitro under flow conditions. J Immunol. 2011; 186:1411-1420. [PubMed: 21178014]

126. Pruenster M, Kurz AR, Chung KJ, et al. Extracellular MRP8/14 is a regulator of beta2 integrindependent neutrophil slow rolling and adhesion. Nat Commun. 2015; 6:6915. [PubMed: 25892652]

127. Springer TA. Adhesion receptors of the immune system. Nature. 1990; 346:425-434. [PubMed: 1974032]

128. Kumar J, Okada S, Clayberger C, Krensky AM. Granulysin: a novel antimicrobial. Expert Opin Investig Drugs. 2001; 10:321-329.

129. Lehrer RI, Lu W. alpha-Defensins in human innate immunity. Immunol Rev. 2012; 245:84-112. [PubMed: 22168415]

130. Howell MD, Gallo RL, Boguniewicz M, et al. Cytokine milieu of atopic dermatitis skin subverts the innate immune response to vaccinia virus. Immunity. 2006; 24:341-348. [PubMed: 16546102]

131. Sun J, Furio L, Mecheri R, et al. Pancreatic beta-Cells Limit Autoimmune Diabetes via an Immunoregulatory Antimicrobial Peptide Expressed under the Influence of the Gut Microbiota. Immunity. 2015; 43:304-317. [PubMed: 26253786]

132. Park JS, Svetkauskaite D, He Q, et al. Involvement of toll-like receptors 2 and 4 in cellular activation by high mobility group box 1 protein. J Biol Chem. 2004; 279:7370-7377. [PubMed: 14660645] 
133. van Zoelen MA, Yang H, Florquin S, et al. Role of Toll-Like Receptors 2 and 4, and the Receptor for Advanced Glycation End Products (Rage) in Hmgb1 Induced Inflammation in Vivo. Shock. 2008

134. Zhang Z, Meng P, Han Y, et al. Mitochondrial DNA-LL-37 Complex Promotes Atherosclerosis by Escaping from Autophagic Recognition. Immunity. 2015; 43:1137-1147. [PubMed: 26680206]

135. Yanai H, Ban T, Wang Z, et al. HMGB proteins function as universal sentinels for nucleic-acidmediated innate immune responses. Nature. 2009; 462:99-103. [PubMed: 19890330]

136. Chotjumlong P, Bolscher JG, Nazmi K, et al. Involvement of the P2X7 purinergic receptor and cJun N-terminal and extracellular signal-regulated kinases in cyclooxygenase- 2 and prostaglandin E2 induction by LL-37. J Innate Immun. 2013; 5:72-83. [PubMed: 23095809]

137. Wan M, Soehnlein O, Tang X, et al. Cathelicidin LL-37 induces time-resolved release of LTB4 and TXA2 by human macrophages and triggers eicosanoid generation in vivo. FASEB J. 2014; 28:3456-3467. [PubMed: 24736410]

138. Vabulas RM, Ahmad-Nejad P, Ghose S, Kirschning CJ, Issels RD, Wagner H. HSP70 as Endogenous Stimulus of the Toll/Interleukin-1 Receptor Signal Pathway. J Biol Chem. 2002; 277:15107-15112. [PubMed: 11842086]

139. Loser K, Vogl T, Voskort M, et al. The Toll-like receptor 4 ligands Mrp8 and Mrp14 are crucial in the development of autoreactive CD8+ T cells. Nat Med. 2010; 16:713-717. [PubMed: 20473308]

140. Palm NW, Medzhitov R. Pattern recognition receptors and control of adaptive immunity. Immunol Rev. 2009; 227:221-233. [PubMed: 19120487]

141. Ibrahim ZA, Armour CL, Phipps S, Sukkar MB. RAGE and TLRs: relatives, friends or neighbours? Mol Immunol. 2013; 56:739-744. [PubMed: 23954397]

142. Sims JE, Smith DE. The IL-1 family: regulators of immunity. Nat Rev Immunol. 2010; 10:89102. [PubMed: 20081871]

143. Latz E, Xiao TS, Stutz A. Activation and regulation of the inflammasomes. Nat Rev Immunol. 2013; 13:397-411. [PubMed: 23702978]

144. Bauernfeind FG, Horvath G, Stutz A, et al. Cutting edge: NF-kappaB activating pattern recognition and cytokine receptors license NLRP3 inflammasome activation by regulating NLRP3 expression. J Immunol. 2009; 183:787-791. [PubMed: 19570822]

145. Mariathasan S, Weiss DS, Newton K, et al. Cryopyrin activates the inflammasome in response to toxins and ATP. Nature. 2006; 440:228-232. [PubMed: 16407890]

146. Lima H Jr, Jacobson LS, Goldberg MF, et al. Role of lysosome rupture in controlling Nlrp3 signaling and necrotic cell death. Cell Cycle. 2013; 12:1868-1878. [PubMed: 23708522]

147. Braga TT, Forni MF, Correa-Costa M, et al. Soluble Uric Acid Activates the NLRP3 Inflammasome. Scientific reports. 2017; 7:39884. [PubMed: 28084303]

148. Grigat J, Soruri A, Forssmann U, Riggert J, Zwirner J. Chemoattraction of macrophages, T lymphocytes, and mast cells is evolutionarily conserved within the human alpha-defensin family. J Immunol. 2007; 179:3958-3965. [PubMed: 17785833]

149. Tyrrell C, De Cecco M, Reynolds NL, et al. Isoleucine/leucine2 is essential for chemoattractant activity of beta-defensin Defb14 through chemokine receptor 6. Mol Immunol. 2010; 47:13781382. [PubMed: 20022113]

150. Rohrl J, Yang D, Oppenheim JJ, Hehlgans T. Specific binding and chemotactic activity of mBD4 and its functional orthologue hBD2 to CCR6-expressing cells. J Biol Chem. 2010; 285:70287034. [PubMed: 20068036]

151. Rohrl J, Yang D, Oppenheim JJ, Hehlgans T. Human beta-defensin 2 and 3 and their mouse orthologs induce chemotaxis through interaction with CCR2. J Immunol. 2010; 184:6688-6694. [PubMed: 20483750]

152. Jin G, Kawsar HI, Hirsch SA, et al. An antimicrobial peptide regulates tumor-associated macrophage trafficking via the chemokine receptor CCR2, a model for tumorigenesis. PLoS One. 2010; 5:e10993. [PubMed: 20544025]

153. Zhang Z, Cherryholmes G, Chang F, Rose DM, Schraufstatter I, Shively JE. Evidence that cathelicidin peptide LL-37 may act as a functional ligand for CXCR2 on human neutrophils. Eur J Immunol. 2009; 39:3181-3194. [PubMed: 19750480] 
154. Orlova VV, Choi EY, Xie C, et al. A novel pathway of HMGB1-mediated inflammatory cell recruitment that requires Mac-1-integrin. EMBO J. 2007; 26:1129-1139. [PubMed: 17268551]

155. Murphy PM. The molecular biology of leukocyte chemoattractant receptors. Annu Rev Immunol. 1994; 12:593-633. [PubMed: 8011292]

156. Zlotnik A, Yoshie O. Chemokines: a new classification system and their role in immunity. Immunity. 2000; 12:121-127. [PubMed: 10714678]

157. Huang HJ, Ross CR, Blecha F. Chemoattractant properties of PR-39, a neutrophil antibacterial peptide. J Leukoc Biol. 1997; 61:624-629. [PubMed: 9129212]

158. Bassi R, Giussani P, Anelli V, et al. HMGB1 as an autocrine stimulus in human T98G glioblastoma cells: role in cell growth and migration. J Neurooncol. 2008; 87:23-33. [PubMed: 17975708]

159. Vongsa RA, Zimmerman NP, Dwinell MB. CCR6 regulation of the actin cytoskeleton orchestrates human beta defensin-2- and CCL20-mediated restitution of colonic epithelial cells. J Biol Chem. 2009; 284:10034-10045. [PubMed: 19233848]

160. Medzhitov R, Janeway C. Innate Immunity. N Engl J Med. 2000; 343:338-344. [PubMed: 10922424]

161. Banchereau J, Steinman RM. Dendritic cells and the control of immunity. Nature. 1998; 392:245251. [PubMed: 9521319]

162. Eickhoff S, Brewitz A, Gerner MY, et al. Robust Anti-viral Immunity Requires Multiple Distinct T Cell-Dendritic Cell Interactions. Cell. 2015; 162:1322-1337. [PubMed: 26296422]

163. Gerner MY, Torabi-Parizi P, Germain RN. Strategically localized dendritic cells promote rapid T cell responses to lymph-borne particulate antigens. Immunity. 2015; 42:172-185. [PubMed: 25607462]

164. Kitano M, Yamazaki C, Takumi A, et al. Imaging of the cross-presenting dendritic cell subsets in the skin-draining lymph node. Proc Natl Acad Sci U S A. 2016; 113:1044-1049. [PubMed: 26755602]

165. Kapsenberg ML. Dendritic-cell control of pathogen-driven T-cell polarization. Nat Rev Immunol. 2003; 3:984-993. [PubMed: 14647480]

166. Victora GD, Nussenzweig MC. Germinal centers. Annu Rev Immunol. 2012; 30:429-457. [PubMed: 22224772]

167. Ma XT, Xu B, An LL, et al. Vaccine with beta-defensin 2-transduced leukemic cells activates innate and adaptive immunity to elicit potent antileukemia responses. Cancer Res. 2006; 66:1169-1176. [PubMed: 16424055]

168. Biragyn A, Belyakov IM, Chow Y-H, Dimitrov DS, Berzofsky JA, Kwak LW. DNA vaccines encoding human immunodeficiency virus-1 glycoprotein 120 fusions with proinflammatory chemoattractants induce systemic and mucosal immune responses. Blood. 2002; 100:1153-1159. [PubMed: 12149191]

169. Chen K, Xiang Y, Huang J, et al. The formylpeptide receptor 2 (Fpr2) and its endogenous ligand cathelin-related antimicrobial peptide (CRAMP) promote dendritic cell maturation. J Biol Chem. 2014; 289:17553-17563. [PubMed: 24808174]

170. Chen K, Le Y, Liu Y, et al. A critical role for the $g$ protein-coupled receptor mFPR2 in airway inflammation and immune responses. Journal of immunology. 2010; 184:3331-3335.

171. Trinchieri G. Interleukin-12 and the regulation of innate resistance and adaptive immunity. Nat Rev Immunol. 2003; 3:133-146. [PubMed: 12563297]

172. Schmitz J, Owyang A, Oldham E, et al. IL-33, an interleukin-1-like cytokine that signals via the IL-1 receptor-related protein ST2 and induces T helper type 2-associated cytokines. Immunity. 2005; 23:479-490. [PubMed: 16286016]

173. Humphreys NE, Xu D, Hepworth MR, Liew FY, Grencis RK. IL-33, a potent inducer of adaptive immunity to intestinal nematodes. J Immunol. 2008; 180:2443-2449. [PubMed: 18250453]

174. Molofsky AB, Savage AK, Locksley RM. Interleukin-33 in Tissue Homeostasis, Injury, and Inflammation. Immunity. 2015; 42:1005-1019. [PubMed: 26084021]

175. Townsend MJ, Fallon PG, Matthews DJ, Jolin HE, McKenzie AN. T1/ST2-deficient mice demonstrate the importance of T1/ST2 in developing primary T helper cell type 2 responses. $\mathrm{J}$ Exp Med. 2000; 191:1069-1076. [PubMed: 10727469] 
176. Louten J, Rankin AL, Li Y, et al. Endogenous IL-33 enhances Th2 cytokine production and T-cell responses during allergic airway inflammation. Int Immunol. 2011; 23:307-315. [PubMed: 21422152]

177. Bonilla WV, Frohlich A, Senn K, et al. The alarmin interleukin-33 drives protective antiviral CD8(+) T cell responses. Science. 2012; 335:984-989. [PubMed: 22323740]

178. Yang H, Lundback P, Ottosson L, et al. Redox modification of cysteine residues regulates the cytokine activity of high mobility group box-1 (HMGB1). Mol Med. 2012; 18:250-259. [PubMed: 22105604]

179. Chen GY, Tang J, Zheng P, Liu Y. CD24 and Siglec-10 selectively repress tissue damage-induced immune responses. Science. 2009; 323:1722-1725. [PubMed: 19264983]

180. Abeyama K, Stern DM, Ito Y, et al. The N-terminal domain of thrombomodulin sequesters highmobility group-B1 protein, a novel antiinflammatory mechanism. J Clin Invest. 2005; 115:12671274. [PubMed: 15841214]

181. Ito T, Kawahara K, Okamoto K, et al. Proteolytic cleavage of high mobility group box 1 protein by thrombin-thrombomodulin complexes. Arterioscler Thromb Vasc Biol. 2008; 28:1825-1830. [PubMed: 18599803]

182. Chiba S, Baghdadi M, Akiba H, et al. Tumor-infiltrating DCs suppress nucleic acid-mediated innate immune responses through interactions between the receptor TIM-3 and the alarmin HMGB1. Nat Immunol. 2012; 13:832-842. [PubMed: 22842346]

183. Hanahan D, Weinberg RA. Hallmarks of cancer: the next generation. Cell. 2011; 144:646-674. [PubMed: 21376230]

184. Yang D, Bustin M, Oppenheim JJ. Harnessing the alarmin HMGN1 for anticancer therapy. Immunotherapy. 2015; 7:1129-1131. [PubMed: 26567750]

185. Wei F, Yang D, Tewary P, et al. The Alarmin HMGN1 Contributes to Antitumor Immunity and Is a Potent Immunoadjuvant. Cancer research. 2014; 74:5989-5998. [PubMed: 25205103]

186. Birger Y, Catez F, Furusawa T, et al. Increased tumorigenicity and sensitivity to ionizing radiation upon loss of chromosomal protein HMGN1. Cancer Res. 2005; 65:6711-6718. [PubMed: 16061652]

187. Krysko DV, Garg AD, Kaczmarek A, Krysko O, Agostinis P, Vandenabeele P. Immunogenic cell death and DAMPs in cancer therapy. Nat Rev Cancer. 2012; 12:860-875. [PubMed: 23151605]

188. Campana L, Bosurgi L, Rovere-Querini P. HMGB1: a two-headed signal regulating tumor progression and immunity. Curr Opin Immunol. 2008; 20:518-523. [PubMed: 18599281]

189. Apetoh L, Ghiringhelli F, Tesniere A, et al. The interaction between HMGB1 and TLR4 dictates the outcome of anticancer chemotherapy and radiotherapy. Immunol Rev. 2007; 220:47-59. [PubMed: 17979839]

190. Apetoh L, Ghiringhelli F, Tesniere A, et al. Toll-like receptor 4-dependent contribution of the immune system to anticancer chemotherapy and radiotherapy. Nat Med. 2007; 13:1050-1059. [PubMed: 17704786]

191. Yan W, Chang Y, Liang X, et al. High-mobility group box 1 activates caspase-1 and promotes hepatocellular carcinoma invasiveness and metastases. Hepatology. 2012; 55:1863-1875. [PubMed: 22234969]

192. Bald T, Quast T, Landsberg J, et al. Ultraviolet-radiation-induced inflammation promotes angiotropism and metastasis in melanoma. Nature. 2014; 507:109-113. [PubMed: 24572365]

193. Kang R, Chen R, Zhang Q, et al. HMGB1 in health and disease. Mol Aspects Med. 2014; 40:1116. [PubMed: 25010388]

194. Markeeva N, Lysovskiy I, Zhuravel E, et al. Involvement of human beta-defensin-2 in proliferation of transformed cells of human cervix. Exp Oncol. 2005; 27:308-313. [PubMed: 16404352]

195. Wenghoefer M, Pantelis A, Dommisch H, et al. Nuclear hBD-1 accumulation in malignant salivary gland tumours. BMC Cancer. 2008; 8:290. [PubMed: 18840281]

196. Kesting MR, Loeffelbein DJ, Hasler RJ, et al. Expression profile of human beta-defensin 3 in oral squamous cell carcinoma. Cancer Invest. 2009; 27:575-581. [PubMed: 19219676] 
197. Shi N, Jin F, Zhang X, Clinton SK, Pan Z, Chen T. Overexpression of human beta-defensin 2 promotes growth and invasion during esophageal carcinogenesis. Oncotarget. 2014; 5:1133311344. [PubMed: 25226614]

198. Xu D, Zhang B, Liao C, et al. Human beta-defensin 3 contributes to the carcinogenesis of cervical cancer via activation of NF-kappaB signaling. Oncotarget. 2016; 7:75902-75913. [PubMed: 27713149]

199. DasGupta T, Nweze EI, Yue H, et al. Human papillomavirus oncogenic E6 protein regulates human beta-defensin 3 (hBD3) expression via the tumor suppressor protein p53. Oncotarget. 2016; 7:27430-27444. [PubMed: 27034006]

200. Sun CQ, Arnold R, Fernandez-Golarz C, et al. Human beta-defensin-1, a potential chromosome $8 \mathrm{p}$ tumor suppressor: control of transcription and induction of apoptosis in renal cell carcinoma. Cancer Res. 2006; 66:8542-8549. [PubMed: 16951166]

201. Wenghoefer M, Pantelis A, Dommisch H, et al. Decreased gene expression of human betadefensin- 1 in the development of squamous cell carcinoma of the oral cavity. Int J Oral Maxillofac Surg. 2008; 37:660-663. [PubMed: 18346877]

202. Schutte BC, Mitros JP, Bartlett JA, et al. Discovery of five conserved beta -defensin gene clusters using a computational search strategy. Proc Natl Acad Sci USA. 2002; 99:2129-2133. [PubMed: 11854508]

203. Onozaki K, Matsushima K, Kleinerman ES, Saito T, Oppenheim JJ. Role of interleukin 1 in promoting human monocyte-mediated tumor cytotoxicity. J Immunol. 1985; 135:314-320. [PubMed: 3873493]

204. Yang D, Hayashi H, Takii T, Mizutani Y, Inukai Y, Onozaki K. Interleukin-1-induced growth inhibition of human melanoma cells. Interleukin-1-induced antizyme expression is responsible for ornithine decarboxylase activity down-regulation. J Biol Chem. 1997; 272:3376-3383. [PubMed: 9013579]

205. Pollock AS, Turck J, Lovett DH. The prodomain of interleukin 1alpha interacts with elements of the RNA processing apparatus and induces apoptosis in malignant cells. FASEB J. 2003; 17:203213. [PubMed: 12554699]

206. Dvorkin T, Song X, Argov S, et al. Immune phenomena involved in the in vivo regression of fibrosarcoma cells expressing cell-associated IL-1alpha. J Leukoc Biol. 2006; 80:96-106. [PubMed: 16707560]

207. Carmi Y, Voronov E, Dotan S, et al. The role of macrophage-derived IL-1 in induction and maintenance of angiogenesis. J Immunol. 2009; 183:4705-4714. [PubMed: 19752225]

208. Qin Y, Ekmekcioglu S, Liu P, et al. Constitutive aberrant endogenous interleukin-1 facilitates inflammation and growth in human melanoma. Molecular cancer research : MCR. 2011; 9:15371550. [PubMed: 21954434]

209. Cataisson C, Salcedo R, Hakim S, et al. IL-1R-MyD88 signaling in keratinocyte transformation and carcinogenesis. J Exp Med. 2012; 209:1689-1702. [PubMed: 22908325]

210. Maywald RL, Doerner SK, Pastorelli L, et al. IL-33 activates tumor stroma to promote intestinal polyposis. Proc Natl Acad Sci U S A. 2015; 112:E2487-2496. [PubMed: 25918379]

211. Xiao P, Wan X, Cui B, et al. Interleukin 33 in tumor microenvironment is crucial for the accumulation and function of myeloid-derived suppressor cells. Oncoimmunology. 2016; 5:e1063772. [PubMed: 26942079]

212. Fang KM, Yang CS, Lin TC, Chan TC, Tzeng SF. Induced interleukin-33 expression enhances the tumorigenic activity of rat glioma cells. Neuro Oncol. 2014; 16:552-566. [PubMed: 24327583]

213. Li J, Razumilava N, Gores GJ, et al. Biliary repair and carcinogenesis are mediated by IL-33dependent cholangiocyte proliferation. J Clin Invest. 2014; 124:3241-3251. [PubMed: 24892809]

214. Kim JY, Lim SC, Kim G, Yun HJ, Ahn SG, Choi HS. Interleukin-33/ST2 axis promotes epithelial cell transformation and breast tumorigenesis via upregulation of COT activity. Oncogene. 2015; 34:4928-4938. [PubMed: 25531326]

215. Ohta S, Tago K, Funakoshi-Tago M, Matsugi J, Yanagisawa K. Intracellular NF-HEV/IL-33 harbors essential roles in Ras-induced cellular transformation by contributing to cyclin D1 protein synthesis. Cell Signal. 2016; 28:1025-1036. [PubMed: 27155324] 
216. Gao K, Li X, Zhang L, et al. Transgenic expression of IL-33 activates CD8(+) T cells and NK cells and inhibits tumor growth and metastasis in mice. Cancer Lett. 2013; 335:463-471. [PubMed: 23499895]

217. Gao X, Wang X, Yang Q, et al. Tumoral expression of IL-33 inhibits tumor growth and modifies the tumor microenvironment through CD8+ T and NK cells. J Immunol. 2015; 194:438-445. [PubMed: 25429071]

218. O'Donnell C, Mahmoud A, Keane J, et al. An antitumorigenic role for the IL-33 receptor, ST2L, in colon cancer. Br J Cancer. 2016; 114:37-43. [PubMed: 26679377]

219. Dominguez D, Ye C, Geng Z, et al. Exogenous IL-33 Restores Dendritic Cell Activation and Maturation in Established Cancer. J Immunol. 2017; 198:1365-1375. [PubMed: 28011934]

220. Ma Y, Aymeric L, Locher C, Kroemer G, Zitvogel L. The dendritic cell-tumor cross-talk in cancer. Curr Opin Immunol. 2011; 23:146-152. [PubMed: 20970973]

221. Blachere NE, Li Z, Chandawarkar RY, et al. Heat shock protein-peptide complexes, reconstituted in vitro, elicit peptide-specific cytotoxic T lymphocyte response and tumor immunity. J Exp Med. 1997; 186:1315-1322. [PubMed: 9334371]

222. Binder RJ, Han DK, Srivastava PK. CD91: a receptor for heat shock protein gp96. Nat Immunol. 2000; 1:151-155. [PubMed: 11248808]

223. Basu S, Binder RJ, Ramalingam T, Srivastava PK. CD91 is a common receptor for heat shock proteins gp96, hsp90, hsp70, and calreticulin. Immunity. 2001; 14:303-313. [PubMed: 11290339]

224. Tamura Y, Peng P, Liu K, Daou M, Srivastava PK. Immunotherapy of tumors with autologous tumor-derived heat shock protein preparations. Science. 1997; 278:117-120. [PubMed: 9311915]

225. Shevtsov MA, Komarova EY, Meshalkina DA, et al. Exogenously delivered heat shock protein 70 displaces its endogenous analogue and sensitizes cancer cells to lymphocytes-mediated cytotoxicity. Oncotarget. 2014; 5:3101-3114. [PubMed: 24797019]

226. di Pietro A, Tosti G, Ferrucci PF, Testori A. The immunological era in melanoma treatment: new challenges for heat shock protein-based vaccine in the advanced disease. Expert Opin Biol Ther. 2011; 11:1395-1407. [PubMed: 21801084]

227. Adinolfi E, Capece M, Franceschini A, et al. Accelerated tumor progression in mice lacking the ATP receptor P2X7. Cancer Res. 2015; 75:635-644. [PubMed: 25542861]

228. Deaglio S, Dwyer KM, Gao W, et al. Adenosine generation catalyzed by CD39 and CD73 expressed on regulatory T cells mediates immune suppression. J Exp Med. 2007; 204:12571265. [PubMed: 17502665]

229. Ohta A, Gorelik E, Prasad SJ, et al. A2A adenosine receptor protects tumors from antitumor T cells. Proc Natl Acad Sci U S A. 2006; 103:13132-13137. [PubMed: 16916931]

230. Antonioli L, Blandizzi C, Pacher P, Hasko G. Immunity, inflammation and cancer: a leading role for adenosine. Nat Rev Cancer. 2013; 13:842-857. [PubMed: 24226193]

231. Cekic C, Sag D, Li Y, Theodorescu D, Strieter RM, Linden J. Adenosine A2B receptor blockade slows growth of bladder and breast tumors. J Immunol. 2012; 188:198-205. [PubMed: 22116822]

232. Beavis PA, Divisekera U, Paget C, et al. Blockade of A2A receptors potently suppresses the metastasis of CD73+ tumors. Proc Natl Acad Sci U S A. 2013; 110:14711-14716. [PubMed: 23964122]

233. Stagg J, Beavis PA, Divisekera U, et al. CD73-deficient mice are resistant to carcinogenesis. Cancer Res. 2012; 72:2190-2196. [PubMed: 22396496]

234. Yui S, Mikami M, Yamazaki M. Induction of apoptotic cell death in mouse lymphoma and human leukemia cell lines by a calcium-binding protein complex, calprotectin, derived from inflammatory peritoneal exudate cells. J Leukoc Biol. 1995; 58:650-658. [PubMed: 7499962]

235. Ghavami S, Kerkhoff C, Los M, Hashemi M, Sorg C, Karami-Tehrani F. Mechanism of apoptosis induced by S100A8/A9 in colon cancer cell lines: the role of ROS and the effect of metal ions. $\mathrm{J}$ Leukoc Biol. 2004; 76:169-175. [PubMed: 15075348]

236. Sinha P, Okoro C, Foell D, Freeze HH, Ostrand-Rosenberg S, Srikrishna G. Proinflammatory S100 proteins regulate the accumulation of myeloid-derived suppressor cells. J Immunol. 2008; 181:4666-4675. [PubMed: 18802069] 
237. Cheng P, Corzo CA, Luetteke N, et al. Inhibition of dendritic cell differentiation and accumulation of myeloid-derived suppressor cells in cancer is regulated by S100A9 protein. $\mathrm{J}$ Exp Med. 2008; 205:2235-2249. [PubMed: 18809714]

238. Taguchi A, Blood DC, del Toro G, et al. Blockade of RAGE-amphoterin signalling suppresses tumour growth and metastases. Nature. 2000; 405:354-360. [PubMed: 10830965]

239. Winter J, Pantelis A, Reich R, et al. Human beta-defensin-1, -2, and -3 exhibit opposite effects on oral squamous cell carcinoma cell proliferation. Cancer Invest. 2011; 29:196-201. [PubMed: 21280982]

240. Bullard RS, Gibson W, Bose SK, et al. Functional analysis of the host defense peptide Human Beta Defensin-1: new insight into its potential role in cancer. Mol Immunol. 2008; 45:839-848. [PubMed: 17868871]

241. Gouwy M, De Buck M, Portner N, et al. Serum amyloid A chemoattracts immature dendritic cells and indirectly provokes monocyte chemotaxis by induction of cooperating $\mathrm{CC}$ and $\mathrm{CXC}$ chemokines. Eur J Immunol. 2015; 45:101-112. [PubMed: 25345597]

242. Cheng N, He R, Tian J, Ye PP, Ye RD. Cutting edge: TLR2 is a functional receptor for acutephase serum amyloid A. J Immunol. 2008; 181:22-26. [PubMed: 18566366]

243. Gasque P. Complement: a unique innate immune sensor for danger signals. Mol Immunol. 2004; 41:1089-1098. [PubMed: 15476920]

244. Verschoor A, Karsten CM, Broadley SP, Laumonnier Y, Kohl J. Old dogs-new tricks: immunoregulatory properties of C3 and C5 cleavage fragments. Immunol Rev. 2016; 274:112126. [PubMed: 27782330] 


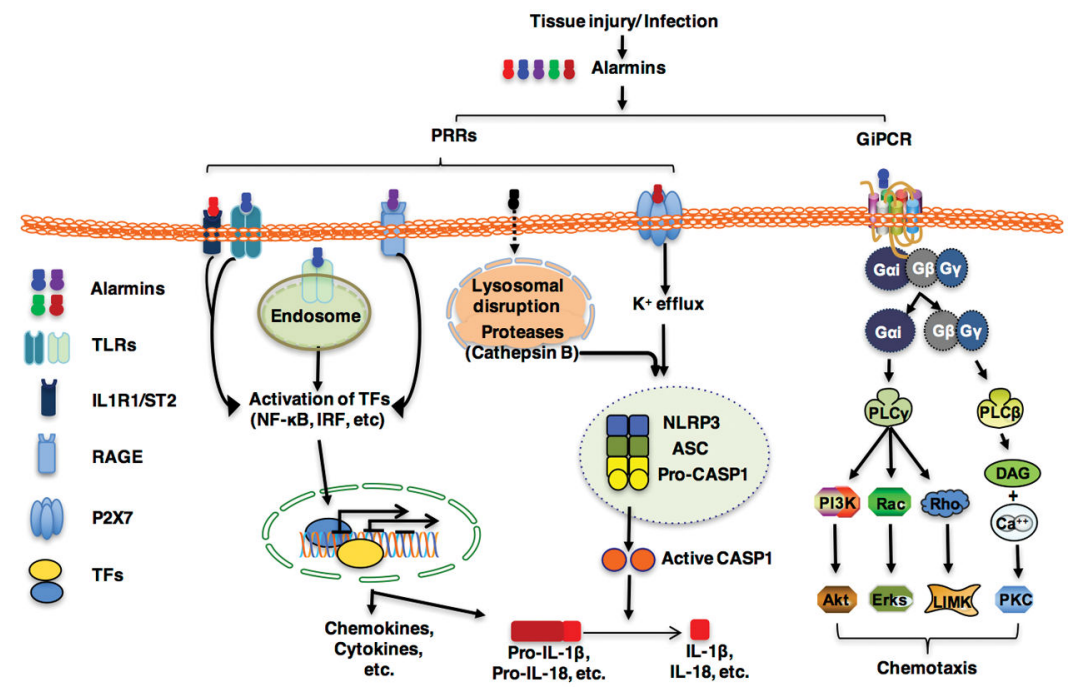

Figure 1.

Signaling pathways triggered by alarmins. Alarmins produced in response to danger (injury or infection) engage primarily pattern-recognition receptors (PRRs) and Gai proteincoupled receptors (GiPCRs) for inducing leukocyte activation and recruitment, respectively. Most alarmins triggers Toll-like recetpors, IL-1R1, ST2, or receptor for advanced glycation endproducts (RAGE) for the activation of various transcription factors (TFs) such as NF- $\kappa B$, IFN-responsive factors (IRFs) that, after nuclear relocation, coordinately promote the transcription of proinflammatory chemokines and cytokines including pro-IL-1 $\beta$ and proIL-18. Some alarmins (e.g. uric acid) internalized as phagocytic vacuoles disrupt lysosome upon fusion, leading to the release of proteases (e.g. cathepsin B) to promote the oligomerization and assembly of NLRP3 inflammasome. Several alarmins (e.g. ATP, cathelicidin, defensins) activate the purinergic receptor $\mathrm{P} 2 \mathrm{X} 7$ to induce $\mathrm{K}^{+}$efflux, which also promotes the oligomerization and assembly of NLRP3 inflammasome. Oligomerization and assembly of NLRP3 inflammasome trigger the cleavage of pro-caspase 1 into active caspase 1 (CASP1) that are responsible for the maturation of IL-1 $\beta$ and IL-18. Most alarmins also interact with GiPCRs (e.g. CCR6, CCR2, P2Ys, etc) to activate phospholipases (PLC $\beta$ or PLC $\gamma$ ). PLC $\beta$ or PLC $\gamma$ induce the activation of PI3K, the small GTPases (Rac and Rho), Akt, Erks, LIMK, and PKC, which coordinately promote cell migration. 
Table 1

Major Categories, Receptors, and Biological Effects of Alarmins

\begin{tabular}{|c|c|c|c|}
\hline Origin & Example & Receptor & Biological effects \\
\hline \multirow[t]{4}{*}{ Granule-derived } & Defensins $(\alpha, \beta)$ & CCR2, CCR6, TLR4 & \multirow{4}{*}{$\begin{array}{l}\text { Antimicrobial } \\
\text { Leukocyte recruitment } \\
\text { DC and } \mathrm{M} \phi \text { activation } \\
\text { Promotion of immune responses }\end{array}$} \\
\hline & Cathelicidin (LL37/CRAMP) & FPRL1, TLR7,8,9, P2X7, EGFR, MrgX2, CXCR2 & \\
\hline & EDN & TLR2 & \\
\hline & Granulysin & TLR4 & \\
\hline \multirow[t]{4}{*}{ Nuclear } & HMGB1 & CXCR4, RAGE, TLR2,4,9 & \multirow{4}{*}{$\begin{array}{l}\text { Regulating gene transcription } \\
\text { Leukocyte recruitment } \\
\text { DC and } \mathrm{M} \phi \text { activation } \\
\text { Promotion of immune responses }\end{array}$} \\
\hline & HMGN1 & TLR4 & \\
\hline & IL-1a & IL-1R & \\
\hline & IL-33 & ST2 & \\
\hline \multirow[t]{4}{*}{ Cytoplasmic } & HSP60,70,90,96 & TLR2,4, CD91 & \multirow{4}{*}{$\begin{array}{l}\text { Cell homeostasis } \\
\text { Leukocyte recruitment } \\
\text { DC and M } \phi \text { activation } \\
\text { Promotion of immune responses }\end{array}$} \\
\hline & S100 proteins & RAGE, TLR4 & \\
\hline & ATP & $\mathrm{P} 2 \mathrm{Y} 2,6,12, \mathrm{P} 2 \mathrm{X} 1,3,7$ & \\
\hline & Uric acid & $\mathrm{P} 2 \mathrm{X} 7$ & \\
\hline
\end{tabular}

Abbreviations used in the table: CRAMP, çathelin-related antimicrobial peptide; EDN, eosinophil-d derived neurotoxin; HMGB1, high- $\underline{\text { mobility }}$ group $\underline{\text { box }} \underline{1}$ protein; HMGN1, high-mobility group nucleosome-binding domain $\underline{1}$ protein; TLR, Toll-like receptor; CCR, $\underline{\text { CC }}$ chemokine receptor; FPRL1, formyl peptide receptor-like $\underline{1}$; EGFR, epidermal growth factor receptor; MrgX2, aas-related gene X2; CXCR, $\underline{\text { CXC }}$ chemokine receptor; RAGE, receptor for advanced glycation end-products; $M \phi$, macrophage. 
Table 2

Effects of Alarmins on Tumor Immunity

\begin{tabular}{|c|c|c|}
\hline Alarmin & Promotor of tumor immunity & Inhibitor of tumor immunity \\
\hline HMGN1 & $\begin{array}{l}\text { Th1 immune response } \\
\text { Tumor-specific CTLs } \\
\text { Antitumor immune protection }\end{array}$ & HMGN1 knockout \\
\hline HMGB 1 & $\begin{array}{l}\text { Th1 immune response } \\
\text { Tumor-specific CTLs } \\
\text { TAA cross-presentation }\end{array}$ & $\begin{array}{l}\text { Angiogenesis } \\
\text { Interacting with TIM-3 } \\
\text { Tumor relapse in } T l r 4^{*} \text { patients }\end{array}$ \\
\hline IL-1a & $\begin{array}{l}\text { Anti-proliferative } \\
\text { Th1 immune response } \\
\text { Tumor-specific CTLs } \\
\text { NK and CTL infiltration }\end{array}$ & $\begin{array}{l}\text { Angiogenesis } \\
\text { Tumor-associated inflammation } \\
\text { Keratinocyte transformation }\end{array}$ \\
\hline IL-33 & $\begin{array}{l}\text { Antitumor immune response } \\
\mathrm{NK} \text { and CTL infiltration }\end{array}$ & $\begin{array}{l}\text { Th2 immune response } \\
\text { ST2 knockout } \\
\text { Tumor cell proliferation } \\
\text { MDSC generation \& recruitment }\end{array}$ \\
\hline Defensins & $\begin{array}{l}\text { Th1 immune response } \\
\text { Tumor-specific CTLs } \\
\text { NK and CTL infiltration }\end{array}$ & $\begin{array}{l}\text { Tumor cell proliferation } \\
\text { Tumor-associated inflammation }\end{array}$ \\
\hline HSPs & $\begin{array}{l}\text { Th1 immune response } \\
\text { Tumor-specific CTLs } \\
\text { TAA cross-presentation } \\
\text { CTL-mediated killing }\end{array}$ & \\
\hline S100A8/A9 & Tumor cell apoptosis & $\begin{array}{l}\text { DC and M } \phi \text { differentiation } \\
\text { MDSC generation \& recruitment } \\
\text { Tumor metastasis } \\
\text { S100A } 8 \text { knockout }\end{array}$ \\
\hline ATP & Antitumor immune response & $\begin{array}{l}\text { Rapid conversion to adenosine } \\
\text { P2X7 knockout }\end{array}$ \\
\hline
\end{tabular}

Abbreviation used in the table: CTL, cytotoxic $\underline{\mathrm{T}}$ lymphocyte; TAA, tumor-associated antigen; TIr $4^{*}$, mutated Tlr4 gene; TIM-3, $\underline{\mathrm{T}}$-cell immunoglobulin and mucin-domain containing- $\underline{3}$; MDSC, myeloid-derived suppressor cell; $\mathrm{M} \phi$, macrophage. 